University of Nebraska - Lincoln

DigitalCommons@University of Nebraska - Lincoln

Publications, Agencies and Staff of the U.S.

Department of Commerce

U.S. Department of Commerce

2013

Bioaccumulation of polychlorinated biphenyls and organochlorine pesticides in young-of-the-year bluefish (Pomatomus saltatrix) in the vicinity of a Superfund Site in New Bedford Harbor, Massachusetts, and in the adjacent waters

\author{
Ashok D. Deshpande \\ James J. Howard Marine Sciences Laboratory at Sandy Hook, ashok.deshpande@noaa.gov \\ Bruce W. Dockum \\ James J. Howard Marine Sciences Laboratory at Sandy Hook \\ Thomas Cleary \\ James J. Howard Marine Sciences Laboratory at Sandy Hook \\ Cameron Farrington \\ James J. Howard Marine Sciences Laboratory at Sandy Hook \\ Daniel Wieczorek \\ James J. Howard Marine Sciences Laboratory at Sandy Hook \\ Follow this and additional works at: https://digitalcommons.unl.edu/usdeptcommercepub
}

\begin{abstract}
Deshpande, Ashok D.; Dockum, Bruce W.; Cleary, Thomas; Farrington, Cameron; and Wieczorek, Daniel, "Bioaccumulation of polychlorinated biphenyls and organochlorine pesticides in young-of-the-year bluefish (Pomatomus saltatrix) in the vicinity of a Superfund Site in New Bedford Harbor, Massachusetts, and in the adjacent waters" (2013). Publications, Agencies and Staff of the U.S. Department of Commerce. 491.

https://digitalcommons.unl.edu/usdeptcommercepub/491
\end{abstract}

This Article is brought to you for free and open access by the U.S. Department of Commerce at DigitalCommons@University of Nebraska - Lincoln. It has been accepted for inclusion in Publications, Agencies and Staff of the U.S. Department of Commerce by an authorized administrator of DigitalCommons@University of Nebraska - Lincoln. 


\title{
Bioaccumulation of polychlorinated biphenyls and organochlorine pesticides in young-of-the-year bluefish (Pomatomus saltatrix) in the vicinity of a Superfund Site in New Bedford Harbor, Massachusetts, and in the adjacent waters
}

\author{
Ashok D. Deshpande*, Bruce W. Dockum, Thomas Cleary, Cameron Farrington, Daniel Wieczorek \\ NOAA Fisheries, James J. Howard Marine Sciences Laboratory at Sandy Hook, Highlands, New Jersey, United States
}

\section{A R T I C L E I N F O}

\section{Keywords:}

New Bedford Harbor

YOY bluefish

PCBs

Organochlorine pesticides

\begin{abstract}
A B S T R A C T
Spatial gradients of polychlorinated biphenyls (PCBs) and organochlorine pesticides were examined in the young-of-the-year (YOY) bluefish (Pomatomus saltatrix) in the vicinity of a PCB Superfund Site in New Bedford Harbor, Massachusetts, and in the adjacent waters. PCB concentrations in bluefish varied between different locations, and also among fish from a given location. A generally decreasing gradient in PCB concentrations was evident as the bluefish were collected away from the Superfund Site. The average sum of PCB concentrations were highest for bluefish collected in the Upper Harbor between Interstate-195 Bridge and Coggeshall Street Bridge (Upper Harbor), followed by bluefish in Lower Harbor from north of Popes Island Bridge (Lower Harbor), and bluefish from Outer Harbor south of Hurricane Barrier (Outer Harbor). The levels of PCBs in bluefish from Clarks Cove and PCBs in bluefish from Buzzards Bay were similar and lowest among all bluefish specimens analyzed in the present study. Pesticide concentrations were about one order of magnitude or lower than the PCB concentrations, and the gradient of pesticide concentrations generally followed the gradient of PCB concentrations. Some of the commonly detected pesticides in the order of decreasing concentrations included DDTs and metabolites, heptachlor epoxide, endosulfan sulfate, and $\alpha$-chlordane. Distribution of PCBs and organochlorine pesticides were examined in the tissues of YOY bluefish from Clarks Cove. PCBs and lipids in the brain samples of YOY bluefish were generally numerically greater than PCBs in the liver samples, but these differences were not statistically significant. PCBs and lipids in hypaxial muscle samples were numerically greater than PCBs in epaxial muscle samples, although these two groups of tissues were not statistically different. Despite the higher susceptibility of lighter PCB homologs to geophysical and biogeochemical weathering processes, the relative dominance of lighter homologs in the Upper Harbor and Lower Harbor samples suggested ongoing or recent sources of these lighter PCBs, particularly Aroclor 1242 and Aroclor 1016 in this area. The presence of heavier homologs in the Upper Harbor and Lower Harbor bluefish samples could be attributed to Aroclor 1252 and Aroclor 1254 that were being used in relatively smaller quantities in the manufacture of electrical components in addition to Aroclor 1242 and Aroclor 1016. The concentration of heavier PCB homologs appears to increase in YOY bluefish the further away from the PCB Superfund Site in the Acushnet Estuary the samples were collected. Principal component analyses of PCB 153 normalized concentrations of the individual PCB congeners resulted in two general groupings; a relatively tight group comprised of YOY bluefish from Upper Harbor, Lower Harbor, and Outer Harbor, and a rather loose and more dispersed group comprised of Buzzards Bay bluefish and the tissue samples of bluefish from Clarks Cove. Principal component analyses of major pesticides suggested close groupings of bluefish from Clarks Cove and bluefish from Buzzards Bay. Pesticides in bluefish from Upper Harbor, Lower Harbor, and Outer Harbor formed a loose group, with some bluefish from these locations populating close to Clarks Cove and Buzzards Bay bluefish. Although PCBs have been implicated in various behavioral and health effects in the experimental and field studies, the deleterious effects of chronic exposure to high concentrations of PCBs and the potential for recruitment of New Bedford Harbor YOY bluefish population to the adult stock remains obscure. Adaptive or evolutionary resistance to contaminants have been documented in resident species in some highly contaminated estuaries, however similar responses have not been investigated in the migratory species like bluefish. The results of the present study provide a reference baseline for YOY bluefish for "before-and-after" comparative studies and other toxicological studies for the New Bedford Harbor Superfund Site that is currently being remediated.
\end{abstract}

Published by Elsevier Ltd.

\footnotetext{
* Corresponding author. Tel.: +1 732872 3043; fax: +1 7328723088.

E-mail address: ashok.deshpande@noaa.gov (A.D. Deshpande).
} 


\section{Introduction}

The Acushnet River watershed, located in the southeastern Massachusetts, has witnessed a variety of agricultural, whaling, fishing, textile, and other busy industrial activities over the past three centuries (Pesch et al., 2011). The estuarine section of the River, commonly referred to as the New Bedford Harbor, has been transformed into a site of major environmental concern due to the operations and disposal practices of different industrial and municipal facilities. Prolonged, heavy, but lawful discharges of PCB contaminated wastes mainly by the two manufacturers of electrical components into the adjacent waters directly, as well as indirectly through the municipal sewer system, have resulted in the severe contamination of the Harbor ecosystem, including sediments, water column, finfish, shellfish, and lobsters (Kolek and Ceruvels, 1981; Weaver, 1984; Lake et al., 1995; Nelson et al., 1996; Pesch et al., 2011; Nelson and Bergen, 2012). In 1979, the Massachusetts Department of Public Health closed the Inner Harbor, referred to as Closed Area I, to the taking of all fish and shellfish (Weaver, 1984, EPA, 2012). The potential for current- and tidal-driven transport of PCB-contaminated sediments from the Inner Harbor to the outside of the Hurricane Barrier and into the Buzzards Bay necessitated additional fishing regulations. Therefore, the Outer Harbor between Ricketsons Point and Wilbur Point, referred to as Closed Area II, was closed to the taking of lobsters and bottom feeding finfish, and Closed Area III in the Buzzards Bay, between Mishaum Point and Rock Point, was prohibited to lobstering. The entire New Bedford Harbor region, extending from the shallow northern reaches of the Acushnet River estuary south through the commercial harbor of New Bedford and into 17,000 adjacent acres of Buzzards Bay, was designated as a Superfund Site in 1982 (EPA ROD, 1998). As per the geographical features and the degrees of contamination, the Superfund Site was subdivided into the Upper Harbor, Lower Harbor, and Outer Harbor. The remedial action includes the removal of approximately 450,000 cubic yards of severely contaminated sediment sites within the Harbor, particularly the sediments above $10 \mathrm{ppm}$ PCBs in the Upper Harbor north of Coggeshall Street and sediments above $50 \mathrm{ppm}$ PCBs in the Lower Harbor and in saltmarshes. As of now, including the hot spot removal, about 250,000 cubic yards of sediments have been removed. Since the 1998 ROD there have been four "Explanation of Significant Differences" (ESDs) that have adjusted the remedy (EPA 2011). With the ESD adjusted remedy, approximately 900,000 cubic yards of sediments will be removed, buried or otherwise remediated. The remedial action will also include the removal of intertidal sediments adjacent to homes or in areas prone to beach combing if PCB levels were above 1 and 25 ppm, respectively. Pesch et al. review (2011) lists additional contaminants of concern in the New Bedford Harbor sediments as copper, chromium, zinc, lead, cyanide, phenols, acids, and biological wastes. These contaminants are associated with various industrial activities related to metalworking and metal plating, printing, petroleum refining, coal-gas production, tanning operations, fish processing plants, processing whale oil, and manufacture of rubber products. These chemicals were taken into account during the risk assessments and the PCB cleanup is expected to remove/cover the metal concentrations of concern as well.

Johnson et al. (1992) reported that out of all the northeast coast sampling sites in the National Benthic Surveillance Project, New Bedford Harbor had the highest level of PCBs in the sediments. The authors reported that the concentrations of DDTs, chlordanes, and polycyclic aromatic hydrocarbons (PAHs) in the sediments at this site ranged from low to moderate. Kimbrough et al. (2008) reported a gradient of PCB concentration in shellfish as the samples were collected away from the Outer Harbor. Thus, 1.41 ppm PCBs were reported in shellfish near Wilbur Point at the southeastern outskirt of the Closed Area 2, the concentrations were followed by 0.632 ppm PCBs near Round Hill at the southwest outskirt of
Closed Area 2, and 0.126 ppm PCBs in Buzzards Bay near Gooseberry Neck, West Point, Massachusetts. PCB concentration in shellfish near Wilbur Point appears to be highest among all shellfish sampled to date in the NOAA Status and Trends Study.

In a survey of PCBs and pesticides in the young-of-the-year (YOY) bluefish from different locations along the U.S. Atlantic coast, we detected relatively elevated levels of PCBs in two samples of bluefish from the Buzzards Bay which is located southwest of the Closed Area 3. The higher PCB levels in these samples prompted our interest to examine the levels of PCBs in YOY bluefish in the vicinity of the Superfund Site. The presence of elevated PCB levels also provided an opportunity to examine the distribution of PCBs in the selected YOY tissue samples.

\section{Materials and methods}

\subsection{Description of the New Bedford Harbor Superfund Site}

The area of Acushnet estuary north of Hurricane Barrier is denoted as the Inner Harbor. This area is divided into two subareas, Upper Harbor and Lower Harbor. The area of New Bedford Harbor north of I-195 Bridge is denoted as Upper Harbor and the area between I-195 Bridge and Hurricane Barrier is denoted as Lower Harbor (EPA ROD, 1998) (Fig. 1). The area south of Hurricane Barrier extending to Mishaum Point, Negro Ledge, and Rock Point is denoted as Outer Harbor. Two electrical capacitor manufacturing facilities that operated between 1940s and 1970s discharged PCB containing wastes either directly into the harbor or indirectly via discharges to the City's sewerage system. Aerovox is located south of Wood Street/ Slocum Street Bridge, and Cornell-Dubilier is located south of Hurricane Barrier. Hot-Spot is defined as an area of about five acres adjacent to Aerovox, where sediment concentrations of PCBs have been reported in excess of $4000 \mathrm{ppm}$. Sawyer Street shoreline Confined Disposal Facility (CDF) is located north of Coggeshall Street Bridge where the Hot-Spot PCB contaminated dredged sediments are pumped in and stored for subsequent treatment and off-site transport to the Toxic Substances Control Act (TSCA) permitted hazardous waste landfill. Fishing Closure Area I represents the area between Wood Street/Slocum Street Bridge and Hurricane Barrier, and these waters are closed to all fishing. Fishing Closure Area II is the area south of Hurricane Barrier to Ricketson's Point and Wilbur Point, and these waters are closed to the taking of lobster, eel, flounder, scup, and tautog. Fishing Closure Area III is the area south of Fishing Closure Area II to Mishaum Point, Negro Ledge and Rock Point, and these waters are closed to lobstering.

\subsection{Collection of YOY bluefish samples}

During summer of 2006, samples of YOY bluefish were collected by hook-and-line at the following locations: (i) Upper Harbor - a site located between Coggeshall Street Bridge and I-195 Bridge, (ii) Lower Harbor - a site located north of Popes Island Bridge, and (iii) Outer Harbor - a site located south of Hurricane Barrier. During summer of 2007, samples of YOY bluefish were collected by hook-and-line at the Clarks Cove entrance. During October 2004, the Massachusetts Division of Marine Fisheries Trawl Survey collected YOY bluefish samples at Station 91 in Buzzards Bay, which is located south of Slocums Neck, Dartmouth, Massachusetts (Fig. 1). All samples were brought on ice to the NOAA Fisheries James J. Howard Marine Sciences Laboratory at Sandy Hook, New Jersey. Each bluefish sample was weighed, measured, and stored at $-20^{\circ} \mathrm{C}$ or $-80^{\circ} \mathrm{C}$ until analyzed.

Higher PCB levels provided an opportunity to examine the distribution and the levels of contaminants in different sensitive organs. Five bluefish from Clarks Cove were selected for dissection 


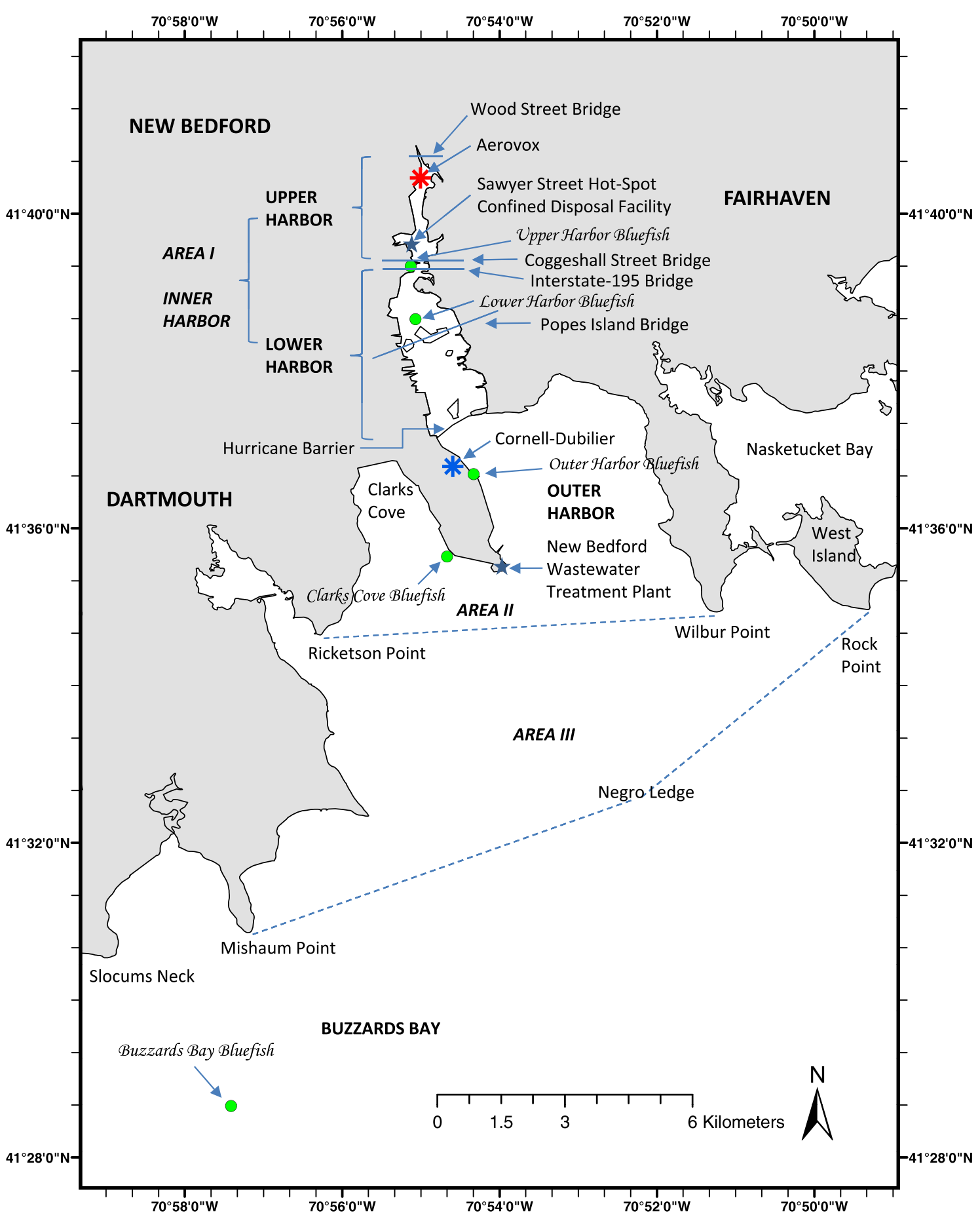

Fig. 1. Locations of YOY bluefish sampling within and in the vicinity of New Bedford Harbor.

as per the following procedure. Based on the length-frequency distributions, the bluefish were placed in the four length bins of 165$169 \mathrm{~mm}, 170-174 \mathrm{~mm}, 175-179 \mathrm{~mm}$, and $180-184 \mathrm{~mm}$, and a random number was assigned to each bluefish. To insure that there was no bias in the selection, one bluefish having the highest random number was selected from each bin. Then, all of the remaining bluefish in different bins were mixed into a common pool. For the selection of additional bluefish, the fish with the highest random number was chosen next from the common pool. If any additional fish were needed to fill out the selection of five fish, the fish with the next highest random number was chosen from the common pool. This latter step was repeated until the total required number of five fish was fulfilled for this Clarks Cove site. The five bluefish selected in this manner were dissected to obtain the following tissue samples: liver, stomach, brain, and muscle as epaxial muscle and hypaxial muscle.

Gnathostome axial myotomes are the primary propulsive muscles that are morphologically divided into epaxial muscle located ventral to the lateral myoseptum and hypaxial muscle located dorsal to the lateral myoseptum (Kusakabe and Kuratani, 2005). Epaxial muscle functions to extend or straighten the spine and provides some lateral flexion, and it is innervated by dorsal ramus of the spinal cord (MSCD, 2012). Hypaxial muscle functions to bend the spine and provides some lateral bending, and it is innervated by ventral ramus of the spinal cord. Although all parts of the fish myomere may be active synchronously during an escape response, the 
kinematics studies indicate that the activation of myomere regions may be highly context-specific (Jayne and Lauder, 1995). Thys (1997) reported activation of epaxial muscle in largemouth bass during dorsocaudal, neurocranial rotation that occurs during prey strike, while Ellerby and Altringham (2001) reported recruitment of hypaxial muscles of rainbow trout during sprinting. Separate samples of epaxial muscle and hypaxial muscle of Clarks Cove bluefish were therefore collected to examine the differences in their lipid and contaminant contents.

Fulton's Condition Factor (K) for each bluefish was calculated as: $\left(K=\frac{100,000 * W}{L^{3}}\right)$, where $L$ is bluefish length in millimeters and $W$ is bluefish weight in grams (Ricker, 1975).

\subsection{Analytical protocol}

Chemical analyses included 8 bluefish specimens from Upper Harbor, 18 bluefish from Lower Harbor, 4 bluefish from Outer Harbor, 5 bluefish from Clarks Cove, and 15 bluefish from Buzzards Bay. YOY bluefish were analyzed by using the general guidelines of Krahn et al. (1988), EPA (1993), Sloan et al. (1993), and Deshpande et al. (2002, 2000). Briefly, the individual, whole YOY bluefish specimens from Buzzards Bay and those from Upper Harbor, Lower Harbor, and Outer Harbor were cut into 15-20 mm thick pieces, freeze-dried, and pulverized using a blender; or minced to smaller pieces using a blender and then manually dried with sodium sulfate using a mortar and a pestle. Method surrogate internal standards (4,4'-dibromooctafluorobiphenyl: Supelco, Bellefonte, Pennsylvania; ronnel: Ultrascientific, North Kingstown, Rhode Island; and PCB 198: AccuStandard, Inc., New Haven, Connecticut) were added to the dried and pulverized homogenates and extracted with methylene chloride (Pesticide Residue Analysis Grade, Fisher Scientific, New Jersey) in a Soxhlet extraction apparatus (Organomation, Berlin, Massachusetts). The individual tissues from Clarks Cove were mixed with diatomaceous earth (Hydromatrix, Dionex Corporation, Sunnyvale, California) and manually dried with a mortar and a pestle. Portions of the remaining body tissue of Clarks Cove bluefish were pulverized using a blender, were mixed with diatomaceous earth, and dried with a mortar and a pestle. Each homogeneous mixture was transferred to a stainless steel extraction cell, and the same method surrogate internal standards used in the Soxhlet extraction were added to each cell. The samples were then extracted with methylene chloride (Pesticide Residue Analysis Grade, Fisher Scientific, New Jersey) by using Dionex Model 300 Accelerated Solvent Extractor (ASE; Dionex Corporation, Sunnyvale, California) in two consequent cycles. The conditions for extraction of each cycle were: temperature at $120^{\circ} \mathrm{C}$, pressure at 1500 -psi, heating time of 6 -min, static time of 5 -min, flush percent 100 , and purge time of 90 -s. After the extraction, anhydrous sodium sulfate was added to each extract to remove the water. This water probably originated from the methylene chloride azeotrope which may have formed during the extraction or the water may have been back extracted from the diatomaceous earth during the rather harsh extraction conditions. The extract was then filtered using a Whatman Phase Separator Circle to remove the traces of water, and the eluant was concentrated using a Zymark TurboVap evaporator.

Bulk polar interfering compounds of biological origin were removed from the extract containing the target analytes by using the florisil/silica/alumina glass column chromatography. Twenty percent of the cleaned extract by volume was used for the gravimetric determination of the lipids. For some samples, this lipid determination was done before the column chromatography. Additional surrogate internal standards (1,2,3-trichlorobenzene: Sigma-Aldrich, Milwaukee, Wisconsin; and PCB 192: AccuStandard, Inc., New Haven, Connecticut) were added to an aliquot of the extract equivalent to about $400 \mathrm{mg}$ lipids, and the lipids and other interferences from the extract were removed on a styrene-divinylbenzene polymer based semi-preparatory, size-exclusion high performance liquid chromatography column (Phenogel $10,600-\mathrm{mm} \times 21.20-\mathrm{mm}$, 100 Å pore size, $10-\mu \mathrm{m}$ particle size; Phenomenex, Torrance, California) by using a HP 1050 High Performance Liquid Chromatograph (HPLC; Agilent, Palo Alto, California; $\lambda=254 \mathrm{~nm}$ ). HPLC fractions containing target analytes were collected as per the calibrated time intervals by using a Foxy Fraction Collector (ISCO, Lincoln, Nebras$\mathrm{ka}$ ). After exchanging the solvent from methylene chloride to hexane, each fraction was concentrated to $5 \mathrm{ml}$, and the extracts were screened for the contaminant levels using an Agilent 5890 Gas Chromatograph (GC) equipped with an electron capture detector (ECD). Contaminant levels detected in the sample screenings were used in the final dilutions or concentrations of the extracts. Gas chromatography internal surrogate standards (2,4,5,6-tetrachloro-m-xylene: Supelco, Bellefonte, Pennsylvania; PCB-103, 3,3',4,4'tetrabromobiphenyl, and octachloronaphthalene; all from AccuStandard, Inc., New Haven, Connecticut) were added to each extract, and the final extracts were then analyzed for the select sets of PCB congeners and organochlorine pesticides. An autosampler (Agilent 7673; Agilent, Palo Alto, California) was used to inject $1 \mu \mathrm{l}$ of sample extract in the splitless injection mode into a fused-silica capillary guard column $(10-\mathrm{m} \times 0.25-\mathrm{mm}$ ID) concatenated to a fused-silica capillary column $(\mathrm{DB}-5,60-\mathrm{m} \times 0.25-\mathrm{mm} \mathrm{ID}, 0.25-\mu \mathrm{m}$ film thickness). The GC column was heated from $50^{\circ}$ to $155^{\circ} \mathrm{C}$ at $5^{\circ} \mathrm{C} / \mathrm{min}$, $155^{\circ} \mathrm{C}$ to $210^{\circ} \mathrm{C}$ at $1{ }^{\circ} \mathrm{C} / \mathrm{min}, 210^{\circ} \mathrm{C}$ to $315^{\circ} \mathrm{C}$ at $4{ }^{\circ} \mathrm{C} / \mathrm{min}$, and held at this temperature for $16 \mathrm{~min}$. Hydrogen was used as a carrier gas, and nitrogen was used as a make-up gas. The carrier gas pressure was held at $19.4 \mathrm{psi}$ for $1 \mathrm{~min}$. It was programmed to $23.2 \mathrm{psi}$ at $0.17 \mathrm{psi} / \mathrm{min}$, to $25.3 \mathrm{psi}$ at $0.04 \mathrm{psi} / \mathrm{min}$, and then, to $29.3 \mathrm{psi}$ at $0.15 \mathrm{psi} / \mathrm{min}$. The carrier gas pressure was held at $29.3 \mathrm{psi}$ for $17 \mathrm{~min}$. The injector temperature was $280^{\circ} \mathrm{C}$ and the detector temperature was $320^{\circ} \mathrm{C}$. The GC column was calibrated by using a primary calibration mixture (a mixture of the PCB Calibration Check Solution C-CCSEC: AccuStandard Inc., New Haven, Connecticut and chlorinated pesticides SRM 2261: National Institute for Standards and Technology (NIST), Gaithersburg, Maryland) and a supplementary calibration mixture (a mixture of PCBs SRM 2274 and chlorinated pesticides SRM 2275: NIST, Gaithersburg, Maryland, and the individual PCBs 87, 132, and 201: AccuStandard, New Haven, Connecticut) containing target analytes and internal standards. Target analyte peaks were quantified by using the internal standard method.

Appropriate internal standards were also added at the beginning of extraction and before the size-exclusion HPLC cleanup step. Each extraction batch contained a method blank and a certified reference material, either CRM Carp-2 (National Research Council of Canada, Ottawa, Ontario) or SRM 1946 Lake Superior Trout (NIST, Gaithersburg, Maryland). Duplicate analyses of SRM 1946 were performed in one of the extraction batches. PCB congener nomenclature followed that of Ballschmiter and Zell (1980). Analyte concentrations are expressed as $\mathrm{mg} / \mathrm{kg}$ (ppm). Aroclor equivalent PCB concentrations were generated by summing the concentrations of PCB congeners 18, 28, 44, 52, 66, 105, 118, 128, 138, 153, 170, 180, $187,195,206,209$; and multiplying this sum by a factor of 2 (NOAA, 1989). GC-MS analyses in the select ion monitoring mode were performed to obtain the reference chromatograms for Aroclor 1016, Aroclor 1242, and Aroclor 1254. Degree of chlorination for the major peaks were based on the mass-to-charge ratios, elution time windows of representative congeners of the respective PCB homologs, and the retention times of $\mathrm{PCB}$ congeners determined by GC-MS analyses of nine PCB congener mixtures C-CSQ-SET (AccuStandard, New Haven, Connecticut).

The following pairs of analytes frequently coeluted under the gas chromatographic conditions, and therefore they were not included in the calculations when coeluted: PCB 8 and alpha-BHC, 
endosulfan I and PCB 101, dieldrin and PCB 87, PCB 77 and PCB 110 , cis-nonchlor and p,p'-DDD, mirex and PCB 169, and octachloronaphthalene and PCB 206. Mono- and dichloro-PCB congeners were not analyzed due to the interferences that occurred in the vicinity of the target analyte peaks which made their identification and quantification difficult. Total DDTs were calculated as the sum of concentrations of DDTs and metabolites. Total chlordanes were calculated as the sum of concentrations of $\alpha$-chlordane, $\gamma$-chlordane, and t-nonachlor. Peaks near the retention times of endrin and PCB 126 were consistently observed in the GC-ECD chromatograms of a number of bluefish sample extracts. Reanalyses of a few select bluefish extracts by GC-MS in the select ion monitoring mode confirmed that both endrin and PCB 126 were absent in these samples, and perhaps all samples. Therefore, the GC-ECD detections of endrin and PCB 126 were considered as the false positive results. One Buzzards Bay bluefish chromatogram showed a small, broad, and unresolved peak near the retention time of PCB 126. If present, the contribution of PCB 126 in this bluefish was

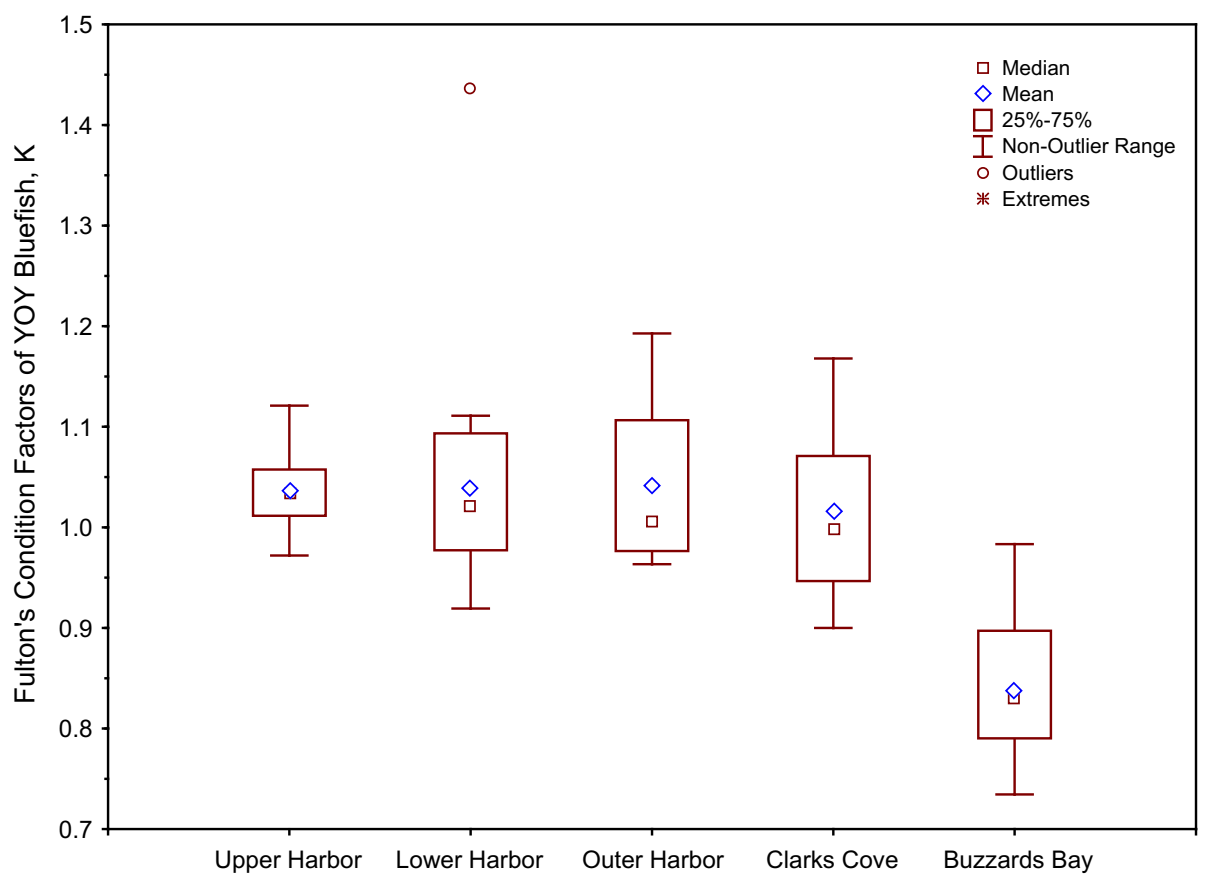

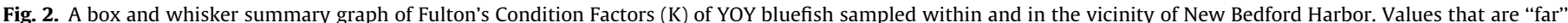

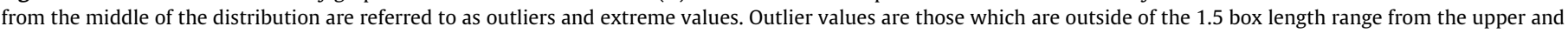
lower values of the box. Extreme values are those which are outside of the 3 box length range from the upper and lower values of the box.

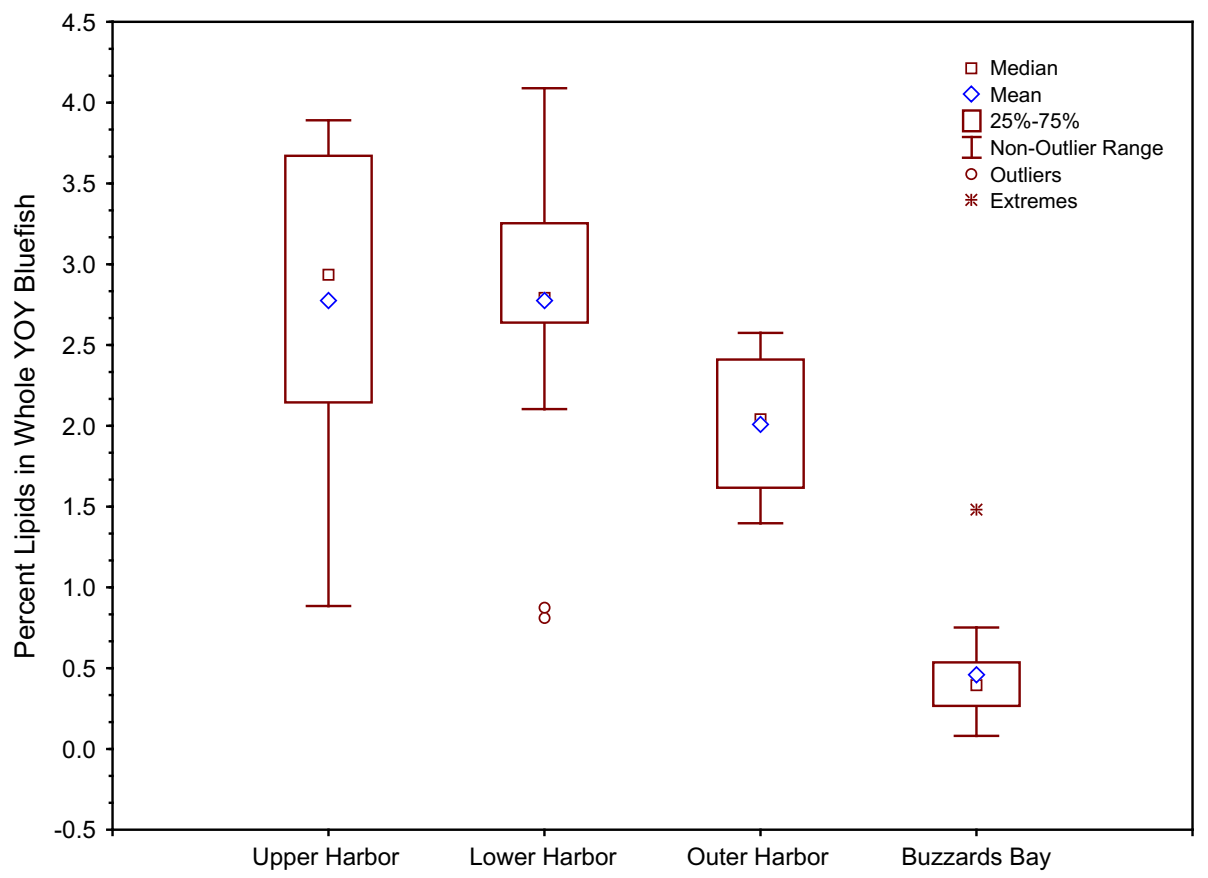

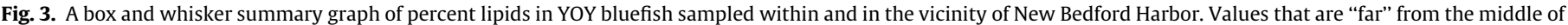

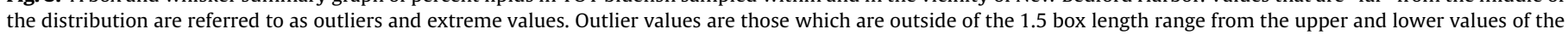
box. Extreme values are those which are outside of the 3 box length range from the upper and lower values of the box. 
deemed minor and inconsequential. Among the PCB congeners, the non-ortho PCBs in fish are assigned the toxic equivalency factor (TEF) of 0.005 , while TEF for all mono-ortho PCBs has been assigned to be $<0.000005$ (Van den Berg et al., 1998 and Van den Berg et al., 2006; EPA, 2008). As the only non-ortho PCB congener with any appreciable TEF value, PCB 126, was shown to be a false positive detection, the dioxin equivalent data sets were considered to be of insignificant importance, and not discussed further. Statistical analyses were performed by using SigmaPlot/SigmaStat 10.0
(Aspire Software International, Ashburn, Virginia) and Statistica 8.0 (StatSoft, Inc; Tulsa, Oklahoma).

\subsection{Quality assurance}

Analyte concentrations in the method blank samples were either mostly non-detects or they were very low compared to the analyte concentrations detected in the bluefish samples. Recoveries of internal standards in Buzzards Bay YOY bluefish

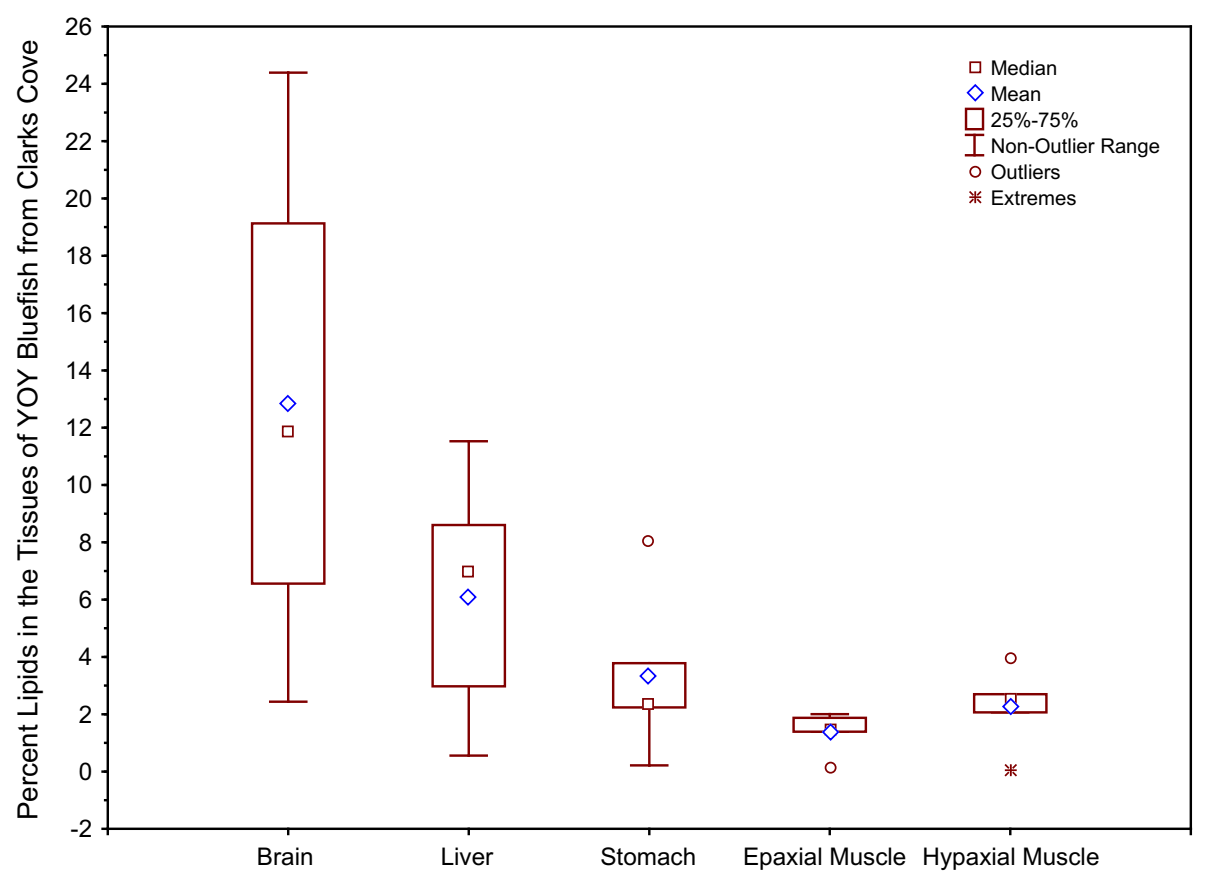

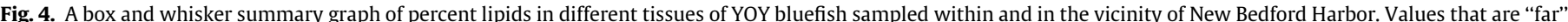

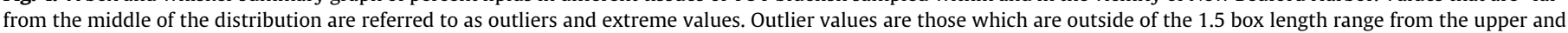
lower values of the box. Extreme values are those which are outside of the 3 box length range from the upper and lower values of the box.

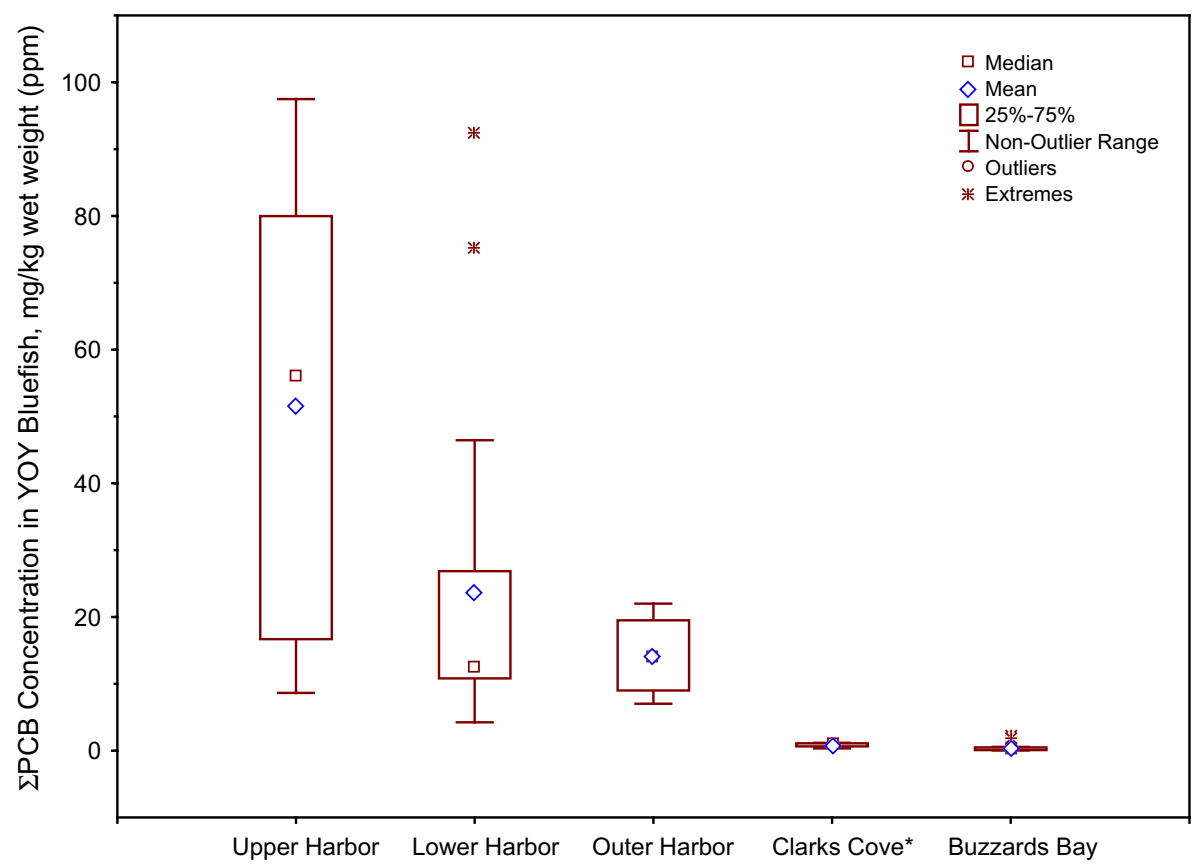

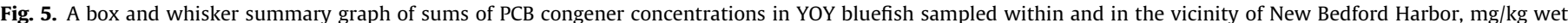

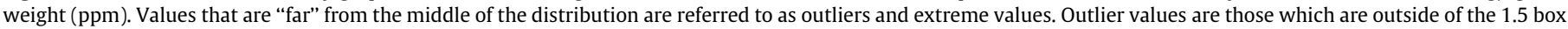

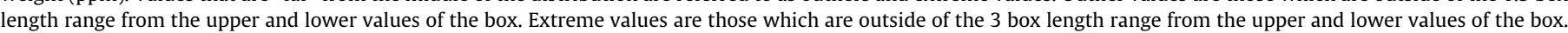


and in tissue samples from Clarks Cove ranged from $11 \%$ to $190 \%$ with an average of $74.4 \pm 33.7 \%$. Internal standard recoveries were below $10 \%$ or above $200 \%$ for 16 of 265 (6\%) values, and were not included in the calculations. Extracts of YOY bluefish from the Upper Harbor, Lower Harbor, and Outer Harbor were highly to moderately contaminated. The intense peaks caused interferences around the internal standard peaks, which resulted in abnormally high recovery values.

We also suspect that some low boiling PCB congeners such as PCB 18 (trichloro-), PCB 28 (trichloro-), PCB 44 (2,2',3,5'-tetrachloro-), and PCB 52 (2,2',5,5'-tetrachloro-) may have cross contaminated from the New Bedford Harbor fish to the CARP-2 reference material during the freeze-drying operation. However, another tetrachloro compound, PCB 66 (2,3',4,4',-tetrachloro-) did not appear to cross contaminate from New Bedford Harbor fish to CARP-2 during the freeze drying operation. Although PCB 44, PCB 52, and PCB 66 are all tetrachloro- compounds, PCB 66 is a mono-ortho PCB, while PCB 44 and PCB 52 are di-ortho PCBs. We think that the greater chlorine substitutions at ortho positions (ortho-effect) would make PCB 44 and PCB 52 more susceptible to volatilization and ensuing cross contamination than PCB 66 (Falconer and Bidleman, 1994; Nakajoh et al., 2005).

With the exclusion of PCB 18, PCB 28, PCB 44, and PCB 52 due to possible cross contamination, and exclusion of one non-detect value for PCB 206 (possibly due to coelution with OCN), the recovery of certified analytes in CARP-2 for three extraction batches $(n=55)$ ranged from $33.4 \%$ to $173 \%$ with an average recovery of $76.3 \pm 27 \%$. For SRM 1946, interferences were observed around PCB 126, PCB 201, lindane, and o, $\mathrm{p}^{\prime}$-DDD peaks, and for PCB 132 in one sample. With the exclusion of these values, the recovery of certified analytes in SRM 1946 in three extraction batches $(n=83)$ ranged from $27.2 \%$ to $164 \%$ with an average recovery of $92.4 \pm 29.8 \%$. For duplicate analyses of 32 analytes in SRM 1946, the percent difference was below $10 \%$ for 23 analytes, and below $20 \%$ for 4 analytes. The percent difference was above $20 \%$ for 5 analytes.

Given the complexity of the multi-step extraction and analytical procedures and the large numbers of variables analyzed, we think that a few deviations in the quality control criteria are not unusual

Table 1

PCBs in YOY bluefish within and in the vicinity of New Bedord Harbor, $\mathrm{mg} / \mathrm{kg}$ wet weight (ppm).

\begin{tabular}{|c|c|c|c|c|c|c|c|c|c|c|}
\hline \multirow{2}{*}{$\begin{array}{l}\text { Location } \\
\text { No. of Samples } \\
\text { Statistics }\end{array}$} & \multicolumn{2}{|c|}{$\begin{array}{l}\text { Upper Harbor }(\mathrm{UH}) \\
(n=8)\end{array}$} & \multicolumn{2}{|c|}{$\begin{array}{l}\text { Lower Harbor }(\mathrm{LH}) \\
(n=18)\end{array}$} & \multicolumn{2}{|c|}{$\begin{array}{l}\text { Outer Harbor }(\mathrm{OH}) \\
(n=4)\end{array}$} & \multicolumn{2}{|c|}{$\begin{array}{l}\text { Clarks Cove }(\mathrm{CC})^{*} \\
(n=4)\end{array}$} & \multicolumn{2}{|c|}{$\begin{array}{l}\text { Buzzards Bay (BB) } \\
(n=15)\end{array}$} \\
\hline & Mean & SD & Mean & SD & Mean & SD & Mean & SD & Mean & SD \\
\hline Weight, g & 64.21 & 13.36 & 88.24 & 14.88 & 44.10 & 7.52 & 53.30 & 2.65 & 19.81 & 2.99 \\
\hline \% Lipids & 2.78 & 1.06 & 2.70 & 0.87 & 2.01 & 0.51 & 4.03 & 2.38 & 0.46 & 0.33 \\
\hline PCB $18(3 \mathrm{Cl})$ & 5.21 & 3.70 & 2.19 & 2.57 & 0.998 & 0.345 & 0.013 & 0.007 & 0.005 & 0.007 \\
\hline PCB $28(3 \mathrm{Cl})$ & 7.16 & 5.17 & 3.01 & 3.51 & 1.45 & 0.629 & 0.029 & 0.013 & 0.011 & 0.019 \\
\hline PCB $31(3 \mathrm{Cl})$ & 6.91 & 5.23 & 2.73 & 3.55 & 1.16 & 0.503 & 0.016 & 0.008 & 0.006 & 0.009 \\
\hline PCB $44(4 \mathrm{Cl})$ & 2.43 & 1.70 & 1.07 & 1.17 & 0.577 & 0.233 & 0.024 & 0.009 & 0.008 & 0.011 \\
\hline PCB $49(4 \mathrm{Cl})$ & 7.06 & 4.94 & 3.17 & 3.46 & 1.73 & 0.754 & 0.063 & 0.030 & 0.027 & 0.040 \\
\hline PCB $52(4 \mathrm{Cl})$ & 7.52 & 5.33 & 3.321 & 3.731 & 1.75 & 0.731 & 0.069 & 0.034 & 0.033 & 0.055 \\
\hline PCB $66(4 \mathrm{Cl})$ & 1.10 & 0.61 & 0.60 & 0.45 & 0.466 & 0.246 & 0.032 & 0.015 & 0.010 & 0.010 \\
\hline РCB $95(5 \mathrm{Cl})$ & 2.53 & 1.73 & 1.17 & 1.26 & 0.713 & 0.330 & 0.044 & 0.020 & 0.027 & 0.038 \\
\hline PCB $99(5 \mathrm{Cl})$ & 2.55 & 1.49 & 1.342 & 1.104 & 1.00 & 0.578 & 0.083 & 0.035 & 0.046 & 0.050 \\
\hline PCB $105(5 \mathrm{Cl})$ & 0.289 & 0.125 & 0.19 & 0.10 & 0.192 & 0.114 & 0.021 & 0.011 & 0.012 & 0.018 \\
\hline PCB $118(5 \mathrm{Cl})$ & 2.04 & 1.09 & 1.163 & 0.822 & 0.988 & 0.589 & 0.103 & 0.046 & 0.070 & 0.098 \\
\hline PCB $126(5 \mathrm{Cl})$ & nd & nd & nd & nd & nd & nd & nd & nd & nd & nd \\
\hline PCB $128(6 \mathrm{Cl})$ & 0.181 & 0.082 & 0.118 & 0.068 & 0.126 & 0.074 & 0.018 & 0.009 & 0.010 & 0.012 \\
\hline PCB $132(6 \mathrm{Cl})$ & 0.141 & 0.086 & 0.106 & 0.060 & 0.113 & 0.077 & 0.018 & 0.005 & 0.007 & 0.009 \\
\hline PCB $138(6 \mathrm{Cl})$ & 1.32 & 0.680 & 0.78 & 0.53 & 0.723 & 0.434 & 0.085 & 0.040 & 0.061 & 0.077 \\
\hline РСВ $149(6 \mathrm{Cl})$ & 1.80 & 1.14 & 0.902 & 0.847 & 0.688 & 0.400 & 0.058 & 0.025 & 0.039 & 0.046 \\
\hline PCB $151(6 \mathrm{Cl})$ & 0.373 & 0.242 & 0.18 & 0.18 & 0.134 & 0.080 & 0.014 & 0.005 & 0.009 & 0.012 \\
\hline PCB $153(6 \mathrm{Cl})$ & 1.93 & 1.05 & 1.088 & 0.815 & 0.945 & 0.582 & 0.111 & 0.052 & 0.076 & 0.097 \\
\hline РCВ $156(6 \mathrm{Cl})$ & 0.117 & 0.061 & 0.069 & 0.049 & 0.068 & 0.045 & 0.009 & 0.005 & 0.005 & 0.008 \\
\hline PCB $170(7 \mathrm{Cl})$ & 0.117 & 0.067 & 0.060 & 0.047 & 0.059 & 0.040 & 0.008 & 0.004 & 0.005 & 0.007 \\
\hline PCB $180(7 \mathrm{Cl})$ & 0.229 & 0.125 & 0.133 & 0.095 & 0.130 & 0.087 & 0.016 & 0.008 & 0.010 & 0.012 \\
\hline РCB $183(7 \mathrm{Cl})$ & 0.104 & 0.058 & 0.056 & 0.044 & 0.053 & 0.031 & 0.008 & 0.004 & 0.004 & 0.006 \\
\hline PCB $187(7 \mathrm{Cl})$ & 0.294 & 0.175 & 0.154 & 0.134 & 0.130 & 0.084 & 0.016 & 0.007 & 0.011 & 0.012 \\
\hline РCВ $194(8 \mathrm{Cl})$ & 0.039 & 0.023 & 0.019 & 0.018 & 0.021 & 0.011 & 0.004 & 0.001 & 0.001 & 0.001 \\
\hline PCB $195(8 \mathrm{Cl})$ & 0.019 & 0.012 & 0.009 & 0.009 & 0.009 & 0.006 & 0.003 & 0.001 & 0.001 & 0.001 \\
\hline PCB $201(8 \mathrm{Cl})$ & 0.040 & 0.023 & 0.021 & 0.016 & 0.022 & 0.012 & 0.004 & 0.001 & 0.001 & 0.001 \\
\hline РСВ 206 (9Cl) & nd & nd & nd & nd & nd & nd & 0.002 & 0.001 & 0.0004 & 0.0003 \\
\hline РСВ 209 (10Cl) & 0.007 & 0.003 & 0.005 & 0.002 & 0.003 & 0.001 & 0.001 & 0.001 & 0.0002 & 0.0001 \\
\hline$\Sigma$ PCBs & 51.5 & 34.5 & 23.7 & 24.4 & 14.3 & 6.6 & 0.872 & 0.371 & 0.497 & 0.654 \\
\hline$\Sigma$ Aroclors & 59.7 & 39.2 & 27.8 & 27.8 & 17.1 & 7.8 & 1.10 & 0.475 & 0.647 & 0.870 \\
\hline 乏PCBs/g lipid & 1785 & 1023 & 792 & 620 & 693 & 229 & 47.0 & 60.7 & 145 & 189 \\
\hline$\Sigma$ Aroclors/g lipid & 2074 & 1152 & 935 & 704 & 832 & 271 & 60.2 & 78.6 & 189 & 249 \\
\hline
\end{tabular}

nd $=$ not detected in any sample.

As 1 of 5 Clarks Cove bluefish carcass samples was lost during processing, only four bluefish were used for these estimates.

Estimated \% lipids in Clarks Cove bluefish $=\left(L_{l} \cdot L_{w}+S_{l} \cdot S_{w}+B_{l} \cdot B_{w}+\mathrm{MH}_{l} \cdot \mathrm{MH}_{\mathrm{w}}+\mathrm{ME}_{\mathrm{l}} \cdot \mathrm{ME}_{\mathrm{w}}+C_{l} \cdot C_{w}\right) / F_{w}$.

Estimated PCBs in Clarks Cove bluefish $=\left(L_{c} \cdot L_{w}+S_{c} \cdot S_{w}+B_{c} \cdot B_{w}+\mathrm{MH}_{\mathrm{c}} \cdot \mathrm{MH}_{\mathrm{w}}+\mathrm{ME}_{\mathrm{c}} \cdot \mathrm{ME}_{\mathrm{w}}+C_{c} \cdot C_{w}\right) / F_{w}$

$L_{l}=\%$ Lipids in liver; $L_{c}=$ PCB concentration in liver; $L_{w}=$ weight of liver tissue.

$S_{I}=\%$ Lipids in stomach; $S_{C}=$ PCB concentration in stomach; $S_{w}=$ weight of stomach tissue.

$B_{l}=\%$ Lipids in brain; $B_{c}=$ PCB concentration in brain; $B_{w}=$ weight of brain tissue.

$\mathrm{MH}_{1}=\%$ Lipids in hypaxial muscle; $\mathrm{MH}_{\mathrm{c}}=\mathrm{PCB}$ concentration in hypaxial muscle; $\mathrm{MH}_{\mathrm{w}}=$ weight of hypaxial muscle tissue.

$\mathrm{ME}_{1}=$ \% Lipids in epaxial muscle; $\mathrm{ME}_{\mathrm{C}}=\mathrm{PCB}$ concentration in epaxial muscle; $\mathrm{MH}_{\mathrm{w}}=$ weight of epaxial muscle tissue.

$C_{l}=\%$ Lipids in remaining carcass; $C_{c}=$ PCB concentration in remaining carcass; $C_{w}=$ weight of remaining carcass.

$F_{w}=$ Fish weight.

\%Lipids and PCB concentrations in Clarks Cove bluefish are estimated values. 
or not unexpected. We believe that the analytical data employed in the present study are of acceptable quality for the purpose of examination of spatial dynamics of PCBs and pesticides in the YOY bluefish populations within and in the vicinity of the New Bedford Harbor.

\section{Results}

\subsection{YOY Bluefish Condition}

Linear and positive length-weight relationships were observed for YOY bluefish from Buzzards Bay $(r=0.8485)$, Outer Harbor $(r=0.9255)$, Lower Harbor $(r=0.9013)$, and Upper Harbor $(r=0.9555)$. However, no such correlation was observed for bluefish from Clarks Cove. Correlation curve slopes for the Upper Harbor bluefish ( slope $=0.9994$ ), Lower Harbor bluefish $($ slope $=0.934$ ) and Outer Harbor bluefish (slope $=0.5879$ ) were higher than correlation line slope for Buzzards Bay bluefish (slope $=0.3693$ ). The correlation curve slopes suggested that, for a given length, bluefish from Upper Harbor, Lower Harbor, and Outer Harbor locations were heavier than bluefish from Buzzards Bay. In addition, Dunn's All Pairwise Multiple Comparison Procedure suggested that Fulton's Condition Factors (K) for bluefish from Upper Harbor, Lower Harbor, Outer Harbor, and Clarks Cove locations were statistically significantly greater than K for Buzzards Bay bluefish (Fig. 2).

\subsection{Lipids}

Lipids in the whole bluefish were highest for bluefish from Upper Harbor and Lower Harbor, and followed in decreasing order by bluefish in Outer Harbor and bluefish in Buzzards Bay (Fig. 3). Lipids in bluefish caught at Upper Harbor ranged from $0.89 \%$ to $3.89 \%$ with an average of $2.78 \%$. Lipids in bluefish from Lower Harbor ranged from $0.81 \%$ to $4.09 \%$ with an average of $2.78 \%$. Lipids from Outer Harbor ranged from $1.40 \%$ to $2.58 \%$ with an average of $2.01 \%$. Lipids were lowest for bluefish from Buzzards Bay, and ranged from $0.08 \%$ to $1.48 \%$ with an average of $0.458 \%$. In Dunn's All Pairwise Multiple Comparison Method, lipids in bluefish from the Upper Harbor and Lower Harbor were statistically significantly higher than lipids in bluefish from Buzzards Bay. Significant differences were not detected in other comparisons.

Lipids in tissues of bluefish from Clarks Cove were highest for the brain tissue, and followed in the decreasing order by liver, stomach, hypaxial muscle, and epaxial muscle (Fig. 4). Lipids in brain ranged from $2.44 \%$ to $24.4 \%$ with an average of $12.9 \%$. Lipids in liver ranged from $0.56 \%$ to $11.5 \%$ with an average of $6.14 \%$. Lipids in stomach ranged from $0.22 \%$ to $8.06 \%$ with an average of $3.34 \%$. Lipids in hypaxial muscle ranged from $0.054 \%$ to $4.0 \%$ with an average of $2.27 \%$. Lipids in epaxial muscle ranged from $0.15 \%$ to $2.0 \%$ with an average of $1.38 \%$. In Tukey All Pairwise Multiple Comparison Test, lipids in brain tissues were significantly higher than lipids in epaxial muscle tissues. Tukey Test did not detect any other significant differences.

\section{3. $P C B s$}

PCB concentrations in YOY bluefish samples varied among different locations, and also among fish from a given location (Fig. 5). A generally decreasing gradient in PCB concentrations was evident as the YOY bluefish samples were collected away from the Superfund Site located in the upper reaches of Acushnet estuary. The average sum of PCB concentrations were highest for bluefish collected in Upper Harbor, followed by bluefish in Lower Harbor, and bluefish from Outer Harbor (Table 1).

Relatively elevated concentrations of PCBs provided us an opportunity to examine the distribution of PCBs in different tissues of bluefish. PCBs are reported for liver, brain, stomach, epaxial muscle and hypaxial muscle tissues of bluefish from Clarks Cove (Fig. 6; Table 2). PCB concentration in the whole Clarks Cove bluefish was also estimated based on $\mathrm{PCB}$

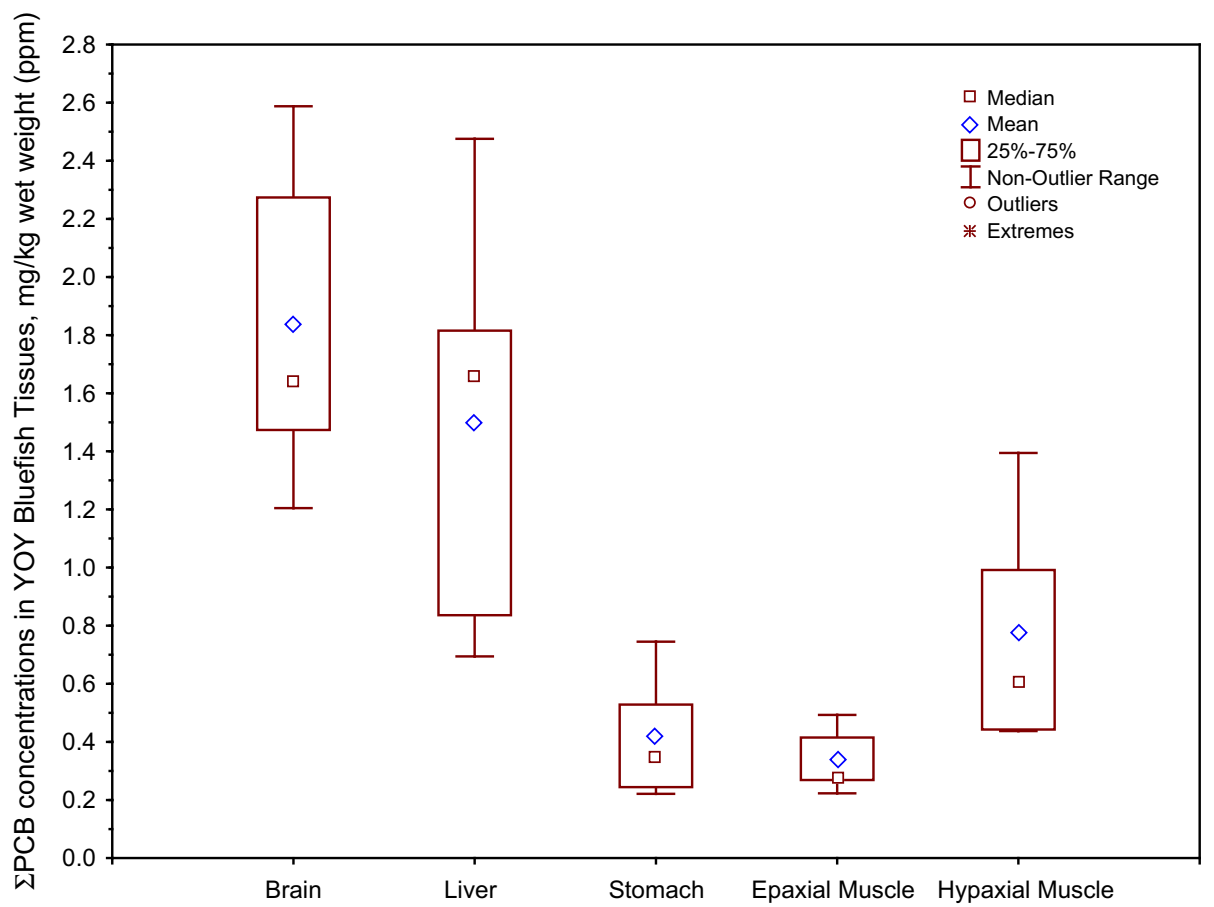

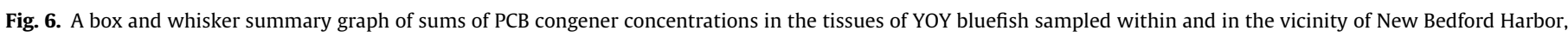

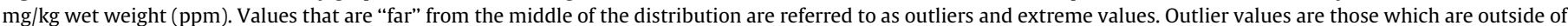

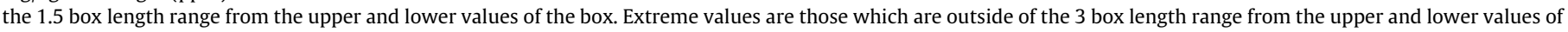
the box. 
concentrations in the individual tissues and in the remaining carcass, and the amounts of individual tissue and the remaining carcass. Estimated PCB concentration in Clarks Cove bluefish and measured PCB concentrations in bluefish from Buzzards Bay were similar and lowest among all bluefish samples analyzed in the present study.

Sums of PCB congeners in select Upper Harbor bluefish (5 of 8 samples) and Lower Harbor bluefish (4 of 18 samples) were fairly high with PCB concentrations ranging from 35.2 to $97.6 \mathrm{ppm}$ (Table 5). These levels were 17.6-48.8 times greater than U.S Food and Drug Administration's tolerance level of $2 \mathrm{ppm}$ PCBs for human seafood consumption (FDA, 1991), and 271-751 times greater than $0.13 \mathrm{ppm}$ criterion suggested by Newell et al. (1987) for the protection of wildlife that are fish consumers. PCBs in the rest of the Upper Harbor and Lower Harbor bluefish samples ranged from 4.24 to $26.9 \mathrm{ppm}$. Bluefish collected from Outer Harbor were moderately contaminated with the PCBs, and the PCB concentrations ranged from 7.05 to $22.1 \mathrm{ppm}$. Although not as high as the Upper Harbor, Lower Harbor or Outer Harbor samples, PCB levels in two of the Buzzards Bay bluefish samples were $1.82 \mathrm{ppm}$ and $2.27 \mathrm{ppm}$, respectively. These concentrations are almost double or higher than PCBs in the rest of the bluefish samples from this location. The relatively high PCB levels in these two bluefish samples formed the basis of the present article as they prompted us to examine the extent of PCB contamination in bluefish near and in the vicinity of the New Bedford Harbor Superfund Site.
Kruskal-Wallis One Way ANOVA on Ranks Test detected differences in the median PCB concentrations among YOY bluefish from different locations, suggesting a potential for statistical differences. Dunn's All Pairwise Multiple Comparison Procedure detected statistically significant differences for PCBs in bluefish from Upper Harbor and PCBs in bluefish from Clarks Cove and Buzzards Bay. PCBs in bluefish from Lower Harbor were significantly different from bluefish from Buzzards Bay, but not from bluefish in Clarks Cove. PCBs in bluefish from these two locations were numerically different but they were not significantly different. PCBs correlated with lipids in bluefish captured from Upper Harbor $(r=0.55)$, from Lower Harbor $(r=0.55)$, and from Outer Harbor $(r=0.75)$, but not in bluefish from Buzzards Bay $(r=0.04)$. PCBs correlated poorly with weight for bluefish from Buzzards Bay $(r=0.14)$, Upper Harbor $(r=0.32)$, Lower Harbor $(r=0.24)$. PCBs correlated well with weight in bluefish from Outer Harbor $(r=0.804)$ and Clarks Cove $(r=0.742)$.

For the individual tissue-based analyses of bluefish from Clarks Cove, the Tukey All Pairwise Multiple Comparison Procedure suggested that PCBs in brain tissues were statistically significantly different than PCBs in stomach and epaxial muscle tissue samples. Tukey Procedure also suggested that PCBs in liver samples were significantly different than in the epaxial muscle samples. Lipids (Fig. 4) and PCBs (Fig. 6) in the brain samples were generally numerically greater than the liver samples, but the differences were not statistically significant. Interestingly, PCBs and lipids in hypaxial muscle samples were numerically greater than PCBs in

Table 2

PCBs in the tissues of YOY bluefish from Clarks Cove, $\mathrm{mg} / \mathrm{kg}$ wet weight (ppm).

\begin{tabular}{|c|c|c|c|c|c|c|c|c|c|c|}
\hline \multirow{2}{*}{$\begin{array}{l}\text { Tissue } \\
\text { No. of Samples } \\
\text { Statistics }\end{array}$} & \multicolumn{2}{|l|}{$\begin{array}{l}\text { Brain } \\
(n=5)\end{array}$} & \multicolumn{2}{|l|}{$\begin{array}{l}\text { Liver } \\
(n=5) \\
\end{array}$} & \multicolumn{2}{|c|}{$\begin{array}{l}\text { Stomach } \\
(n=5)\end{array}$} & \multicolumn{2}{|c|}{$\begin{array}{l}\text { Epaxial muscle } \\
(n=5)\end{array}$} & \multicolumn{2}{|c|}{$\begin{array}{l}\text { Hypaxial muscle } \\
(n=5)\end{array}$} \\
\hline & Mean & SD & Mean & SD & Mean & SD & Mean & SD & Mean & SD \\
\hline Weight & 0.099 & 0.017 & 0.431 & 0.122 & 1.594 & 0.700 & 7.711 & 2.862 & 6.113 & 1.694 \\
\hline \% Lipids & 12.89 & 8.97 & 6.13 & 4.39 & 3.34 & 2.93 & 1.38 & 0.73 & 2.27 & 1.43 \\
\hline PCB $18(3 \mathrm{Cl})$ & 0.086 & 0.029 & 0.039 & 0.012 & 0.010 & 0.003 & 0.007 & 0.002 & 0.012 & 0.004 \\
\hline PCB $28(3 \mathrm{Cl})$ & 0.065 & 0.015 & 0.044 & 0.018 & 0.012 & 0.004 & 0.010 & 0.004 & 0.021 & 0.010 \\
\hline PCB $31(3 \mathrm{Cl})$ & 0.053 & 0.019 & 0.036 & 0.019 & 0.010 & 0.002 & 0.006 & 0.002 & 0.011 & 0.005 \\
\hline PCB $44(4 \mathrm{Cl})$ & 0.085 & 0.030 & 0.111 & 0.110 & 0.032 & 0.046 & 0.017 & 0.012 & 0.019 & 0.007 \\
\hline PCB $49(4 \mathrm{Cl})$ & 0.129 & 0.074 & 0.100 & 0.054 & 0.029 & 0.013 & 0.022 & 0.011 & 0.050 & 0.031 \\
\hline PCB $52(4 \mathrm{Cl})$ & 0.205 & 0.068 & 0.130 & 0.074 & 0.038 & 0.021 & 0.029 & 0.015 & 0.058 & 0.031 \\
\hline PCB $66(4 \mathrm{Cl})$ & 0.049 & 0.023 & 0.055 & 0.040 & 0.013 & 0.007 & 0.010 & 0.004 & 0.029 & 0.010 \\
\hline PCB $95(5 \mathrm{Cl})$ & 0.105 & 0.065 & 0.078 & 0.043 & 0.023 & 0.011 & 0.018 & 0.008 & 0.039 & 0.024 \\
\hline PCB 99 (5Cl) & 0.129 & 0.063 & 0.122 & 0.065 & 0.033 & 0.016 & 0.029 & 0.013 & 0.068 & 0.042 \\
\hline PCB $105(5 \mathrm{Cl})$ & 0.039 & 0.031 & 0.027 & 0.017 & 0.007 & 0.004 & 0.006 & 0.002 & 0.016 & 0.012 \\
\hline PCB $118(5 \mathrm{Cl})$ & 0.169 & 0.062 & 0.163 & 0.090 & 0.043 & 0.023 & 0.037 & 0.017 & 0.085 & 0.048 \\
\hline PCB $126(5 \mathrm{Cl})$ & nd & nd & nd & nd & nd & nd & nd & nd & nd & nd \\
\hline PCB $128(6 \mathrm{Cl})$ & 0.025 & 0.013 & 0.023 & 0.013 & 0.007 & 0.004 & 0.005 & 0.001 & 0.014 & 0.009 \\
\hline PCB $132(6 \mathrm{Cl})$ & 0.056 & 0.054 & 0.022 & 0.008 & 0.007 & 0.004 & 0.012 & 0.012 & 0.045 & 0.050 \\
\hline PCB $138(6 \mathrm{Cl})$ & 0.127 & 0.043 & 0.113 & 0.055 & 0.032 & 0.015 & 0.029 & 0.010 & 0.077 & 0.050 \\
\hline РСВ $149(6 \mathrm{Cl})$ & 0.102 & 0.046 & 0.098 & 0.053 & 0.028 & 0.013 & 0.021 & 0.009 & 0.049 & 0.031 \\
\hline PCB $151(6 \mathrm{Cl})$ & 0.040 & 0.034 & 0.029 & 0.017 & 0.010 & 0.007 & 0.006 & 0.002 & 0.010 & 0.006 \\
\hline PCB $153(6 \mathrm{Cl})$ & 0.185 & 0.055 & 0.160 & 0.074 & 0.043 & 0.022 & 0.042 & 0.016 & 0.107 & 0.063 \\
\hline PCB $156(6 \mathrm{Cl})$ & 0.010 & 0.004 & 0.009 & 0.004 & 0.003 & 0.002 & 0.003 & 0.001 & 0.008 & 0.005 \\
\hline РCB $170(7 \mathrm{Cl})$ & 0.013 & 0.004 & 0.012 & 0.006 & 0.003 & 0.002 & 0.003 & 0.001 & 0.006 & 0.005 \\
\hline PCB $180(7 \mathrm{Cl})$ & 0.048 & 0.024 & 0.024 & 0.010 & 0.007 & 0.003 & 0.006 & 0.002 & 0.015 & 0.010 \\
\hline PCB $183(7 \mathrm{Cl})$ & 0.009 & 0.001 & 0.014 & 0.008 & 0.004 & 0.004 & 0.003 & 0.001 & 0.006 & 0.004 \\
\hline PCB $187(7 \mathrm{Cl})$ & 0.043 & 0.021 & 0.029 & 0.013 & 0.009 & 0.005 & 0.006 & 0.001 & 0.015 & 0.010 \\
\hline РСВ $194(8 \mathrm{Cl})$ & 0.020 & 0.008 & 0.012 & 0.006 & 0.004 & 0.003 & 0.003 & 0.002 & 0.003 & 0.001 \\
\hline PCB $195(8 \mathrm{Cl})$ & 0.021 & NA & 0.013 & 0.005 & 0.003 & 0.001 & 0.002 & 0.001 & 0.004 & 0.002 \\
\hline PCB $201(8 \mathrm{Cl})$ & 0.012 & NA & 0.014 & 0.004 & 0.003 & 0.002 & 0.002 & 0.001 & 0.004 & 0.001 \\
\hline РСВ 206 (9Cl) & 0.021 & 0.013 & 0.0126 & 0.010 & 0.003 & 0.003 & 0.002 & 0.002 & 0.001 & 0.001 \\
\hline РСВ 209 (10Cl) & 0.014 & 0.009 & 0.0054 & 0.004 & 0.001 & 0.001 & 0.001 & 0.000 & 0.001 & 0.000 \\
\hline$\Sigma$ PCBs & 1.84 & 0.575 & 1.51 & 0.736 & 0.418 & 0.219 & 0.336 & 0.113 & 0.774 & 0.413 \\
\hline$\Sigma$ Aroclors & 2.36 & 0.671 & 1.88 & 0.940 & 0.526 & 0.292 & 0.423 & 0.142 & 0.960 & 0.516 \\
\hline$\Sigma$ PCBs/g lipid & 30.5 & 36.1 & 89.3 & 136 & 45.4 & 66.7 & 47.4 & 56.4 & 249 & 486 \\
\hline$\Sigma$ Aroclors/g lipid & 40.4 & 50.4 & 110 & 174 & 55.8 & 80.6 & 60.6 & 73.4 & 317 & 622 \\
\hline
\end{tabular}

nd $=$ not detected in sample.

$\mathrm{NA}=$ these analytes were detected in only one of five samples. 


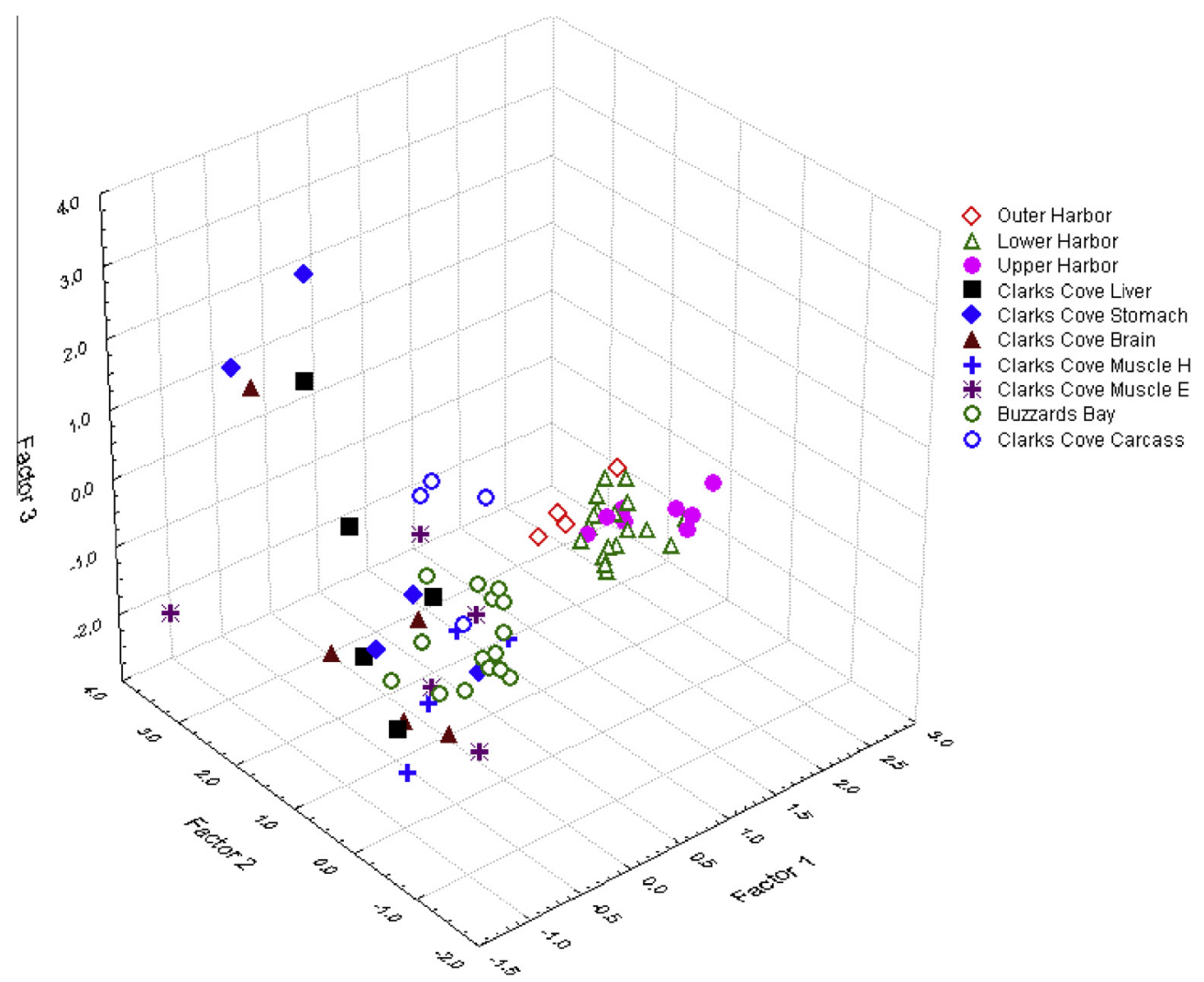

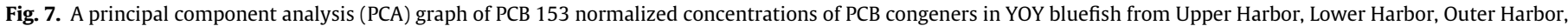
and Buzzards Bay, and PCB 153 normalized concentrations of PCB congeners in different tissues of YOY bluefish from Clarks Cove.

epaxial muscle samples; however PCBs in these two groups of tissues were not statistically different. PCBs negatively correlated with lipids in liver $(r=0.515)$, stomach $(r=0.478)$, and brain $(r=0.648)$. PCBs positively correlated with lipids in epaxial muscle $(r=0.403)$. Correlation between PCBs and lipids in hypaxial muscle was positive, but poor $(r=0.168)$.

The principal component analyses of the PCB 153 normalized concentrations of the individual PCB congeners resulted in two general groupings (Fig. 7). A relatively tight group to the right side of the graph comprised of YOY bluefish from Upper Harbor, Lower Harbor, and Outer Harbor, while the rather loose and more dispersed group to the left side comprised of Buzzards Bay bluefish and tissue samples of bluefish from Clarks Cove. The grouping pattern was approximately similar when the Upper Harbor, Lower Harbor, Outer Harbor, and Buzzards Bay bluefish were compared, although the grouping of Upper Harbor, Lower Harbor, and Outer Harbor bluefish became more dispersed.

\subsection{Pesticides}

Pesticide concentrations in YOY bluefish were about one magnitude or lower than the PCB concentrations in these fish (Tables 3 and 4). Some of the commonly detected pesticides in the order of decreasing concentrations included DDTs and metabolites, heptachlor epoxide, endosulfan sulfate, and $\alpha$-chlordane, and the gradient of pesticide concentrations generally followed the gradient of PCB concentrations.

\subsection{DDTs}

Sum of the DDTs and metabolites, also referred to as total DDTs, in bluefish from Upper Harbor ranged from 0.119 to $1.55 \mathrm{ppm}$ with an average of $0.71 \mathrm{ppm}$ (Fig. 8). Total DDTs in bluefish in Lower Harbor ranged from 0.061 to $0.99 \mathrm{ppm}$ with an average of $0.34 \mathrm{ppm}$. DDTs in Outer Harbor ranged from 0.14 to $0.55 \mathrm{ppm}$ with an average of $0.33 \mathrm{ppm}$. DDTs in bluefish from Clarks Cove and bluefish from Buzzards Bay were lowest with averages of 0.053 and 0.023 ppm, respectively. Dunn's All Pairwise Multiple Comparison Test detected significant differences between DDTs in bluefish from Buzzards Bay and DDTs in bluefish from Upper Harbor, Lower Harbor, and Outer Harbor locations. No other statistical differences were detected for the DDT levels. DDTs were highest in brain tissues of Clarks Cove bluefish, and DDT levels were followed in decreasing order by liver, stomach, hypaxial muscle and epaxial muscle (Fig. 9). DDTs in brain tissue were significantly different and greater than DDTs in epaxial muscle. No other tissuespecific statistical differences were detected. DDTs correlated with lipids in liver $(r=0.39)$, stomach $(r=0.47)$, brain $(r=0.82)$, and hypaxial muscle $(r=0.42)$. DDTs correlated poorly with weight for bluefish from Buzzards Bay $(r=0.005)$, Upper Harbor $(r=0.31)$, and Lower Harbor $(r=0.34)$. DDTs correlated moderately with weight for bluefish from Clarks Cove $(r=0.514)$, and well with bluefish weight for Outer Harbor bluefish $(r=0.921)$.

\subsection{Heptachlor epoxide}

Heptachlor epoxide in bluefish caught from Upper Harbor ranged from 0.018 to $0.20 \mathrm{ppm}$ with an average of $0.11 \mathrm{ppm}$. This pesticide ranged from 0.009 to $0.17 \mathrm{ppm}$ in bluefish from Lower Harbor with an average of $0.055 \mathrm{ppm}$. It ranged from 0.018 to $0.066 \mathrm{ppm}$ in bluefish south of Outer Harbor with an average of $0.04 \mathrm{ppm}$. Heptachlor epoxide was lowest in bluefish from Clarks Cove and bluefish from Buzzards Bay with averages of $0.004 \mathrm{ppm}$ and $0.001 \mathrm{ppm}$, respectively. Dunn's All Pairwise Multiple 
Table 3

Organochlorine pesticides in YOY bluefish within and in the vicinity of New Bedord Harbor, mg/kg wet weight (ppm).

\begin{tabular}{|c|c|c|c|c|c|c|c|c|c|c|}
\hline \multirow{2}{*}{$\begin{array}{l}\text { Location } \\
\text { No. of Samples } \\
\text { Statistics }\end{array}$} & \multicolumn{2}{|c|}{$\begin{array}{l}\text { Upper Harbor } \\
(n=8)\end{array}$} & \multicolumn{2}{|c|}{$\begin{array}{l}\text { Lower Harbor } \\
(n=18)\end{array}$} & \multicolumn{2}{|c|}{$\begin{array}{l}\text { Outer Harbor } \\
(n=4)\end{array}$} & \multicolumn{2}{|c|}{$\begin{array}{l}\text { Clarks Cove } \\
(n=4)\end{array}$} & \multicolumn{2}{|c|}{$\begin{array}{l}\text { Buzzards Bay } \\
(n=15)\end{array}$} \\
\hline & Mean & SD & Mean & SD & Mean & SD & Mean & SD & Mean & SD \\
\hline Weight, g & 64.21 & 13.36 & 88.24 & 14.88 & 44.10 & 7.52 & 53.30 & 2.65 & 19.81 & 2.99 \\
\hline \% Lipids & 2.78 & 1.06 & 2.70 & 0.87 & 2.01 & 0.51 & 4.03 & 2.38 & 0.46 & 0.33 \\
\hline $\mathrm{HCB}$ & 0.0036 & 0.0033 & 0.0039 & 0.0029 & 0.0022 & 0.0009 & 0.0020 & 0.0006 & 0.0003 & 0.0002 \\
\hline b-BHC & nd & nd & nd & nd & 0.0097 & 0.0160 & 0.0097 & 0.0080 & 0.0004 & 0.0006 \\
\hline Lindane & nd & nd & 0.0005 & 0.0022 & nd & nd & 0.0020 & 0.0010 & 0.0007 & 0.0020 \\
\hline Heptachlor & nd & nd & nd & nd & nd & nd & 0.0009 & 0.0005 & 0.0002 & 0.0002 \\
\hline Heptachlor Epoxide & 0.107 & 0.0637 & 0.0553 & 0.0469 & 0.0402 & 0.0215 & 0.0036 & 0.0007 & 0.0013 & 0.0021 \\
\hline Oxychlordane & nd & nd & nd & nd & 0.0024 & 0.0048 & 0.0004 & 0.0002 & 0.0002 & 0.0002 \\
\hline g-Chlordane & 0.0023 & 0.0036 & 0.0019 & 0.0039 & 0.0028 & 0.0042 & 0.0009 & 0.0007 & 0.0004 & 0.0003 \\
\hline a-Chlordane & 0.0620 & 0.0423 & 0.0298 & 0.0309 & 0.0213 & 0.0112 & 0.0027 & 0.0007 & 0.0014 & 0.0011 \\
\hline t-Nonachlor & 0.0089 & 0.0050 & 0.0061 & 0.0044 & 0.0048 & 0.0025 & 0.0019 & 0.0004 & 0.0010 & 0.0008 \\
\hline Endrin & nd & nd & nd & nd & nd & nd & nd & nd & nd & nd \\
\hline Endosulfan I & nd & nd & 0.0455 & 0.152 & 0.362 & 0.724 & 0.0559 & 0.0288 & 0.0188 & 0.0546 \\
\hline Endosulfan II & nd & nd & nd & nd & 0.0035 & 0.0070 & 0.0024 & 0.0037 & 0.0016 & 0.0043 \\
\hline Endosulfan Sulfate & 0.0822 & 0.0537 & 0.0424 & 0.0441 & 0.0419 & 0.0211 & 0.0037 & 0.0010 & 0.0021 & 0.0022 \\
\hline$o, \mathrm{p}^{\prime}-\mathrm{DDE}$ & 0.101 & 0.2851 & 0.0085 & 0.0363 & 0.0402 & 0.0804 & 0.0137 & 0.0062 & 0.0037 & 0.0052 \\
\hline $\mathrm{p}, \mathrm{p}^{\prime}-\mathrm{DDE}$ & 0.211 & 0.0969 & 0.134 & 0.0762 & 0.128 & 0.0673 & 0.0187 & 0.0092 & 0.0109 & 0.0065 \\
\hline $0, \mathrm{p}^{\prime}-\mathrm{DDD}$ & 0.275 & 0.181 & 0.135 & 0.138 & 0.0995 & 0.0638 & 0.0100 & 0.0039 & 0.0029 & 0.0040 \\
\hline $\mathrm{o}, \mathrm{p}^{\prime}-\mathrm{DDT}$ & 0.119 & 0.0906 & 0.0590 & 0.0505 & 0.0611 & 0.0556 & 0.0094 & 0.0031 & 0.0052 & 0.0061 \\
\hline $\mathrm{p}, \mathrm{p}^{\prime}-\mathrm{DDT}$ & nd & nd & 0.0004 & 0.0010 & 0.0006 & 0.0013 & 0.0016 & 0.0012 & 0.0007 & 0.0005 \\
\hline$\Sigma$ DDTs & 0.705 & 0.489 & 0.337 & 0.257 & 0.330 & 0.176 & 0.0529 & 0.0217 & 0.0234 & 0.0194 \\
\hline$\Sigma$ chlordanes & 0.0732 & 0.0457 & 0.0378 & 0.0371 & 0.0289 & 0.0126 & 0.0055 & 0.0005 & 0.0027 & 0.002 \\
\hline$\Sigma$ DDTs/g lipid & 23.6 & 10.1 & 11.7 & 6.42 & 15.5 & 4.86 & 2.55 & 2.92 & 6.80 & 6.58 \\
\hline ¿chlordanes/g lipid & 2.55 & 1.24 & 1.27 & 0.908 & 1.39 & 0.315 & 0.266 & 0.306 & 0.751 & 0.567 \\
\hline
\end{tabular}

nd $=$ not detected in sample.

As 1 of 5 Clarks Cove bluefish carcass samples was lost during processing, only four bluefish were used for these estimates.

Estimated \% lipids in Clarks Cove bluefish $=\left(L_{l} \cdot L_{w}+S_{l} \cdot S_{w}+B_{l} \cdot B_{w}+\mathrm{MH}_{l} \cdot \mathrm{MH}_{\mathrm{w}}+\mathrm{ME}_{\mathrm{l}} \cdot \mathrm{ME}_{\mathrm{w}}+C_{l} \cdot C_{w}\right) / F_{w}$.

Estimated pesticides in Clarks Cove bluefish $=\left(L_{c} \cdot L_{w}+S_{c} \cdot S_{w}+B_{c} \cdot B_{w}+\mathrm{MH}_{\mathrm{c}} \cdot \mathrm{MH}_{\mathrm{w}}+\mathrm{ME}_{\mathrm{c}} \cdot \mathrm{ME}_{\mathrm{w}}+C_{c} \cdot C_{w}\right) / F_{w}$.

$L_{l}=$ \% Lipids in liver; $L_{c}=$ Pesticide concentration in liver; $L_{w}=$ Weight of liver tissue.

$S_{l}=\%$ Lipids in stomach; $S_{c}=$ Pesticide concentration in stomach; $S_{w}=$ Weight of stomach tissue.

$B_{l}=\%$ Lipids in brain; $B_{c}=$ Pesticide concentration in brain; $B_{w}=$ Weight of brain tissue.

$\mathrm{MH}_{1}=\%$ Lipids in hypaxial muscle; $\mathrm{MH}_{\mathrm{c}}=$ Pesticide concentration in hypaxial muscle; $\mathrm{MH}_{\mathrm{w}}=$ Weight of hypaxial muscle tissue .

$\mathrm{ME}_{1}=\%$ Lipids in epaxial muscle; $\mathrm{ME}_{\mathrm{c}}=$ Pesticide concentration in epaxial muscle; $\mathrm{MH}_{\mathrm{W}}=$ Weight of epaxial muscle tissue.

$C_{l}=\%$ Lipids in remaining carcass; $C_{c}=$ Pesticide concentration in remaining carcass; $C_{w}=$ Weight of remaining carcass.

$F_{w}=$ Fish weight.

\%Lipids and Pesticide concentrations in Clarks Cove bluefish are estimated values.

Comparison Test detected significant differences between heptachlor epoxide in bluefish from Buzzards Bay and in bluefish from Upper Harbor and Lower Harbor. Heptachlor epoxide in bluefish from Clarks Cove was also significantly different than heptachlor epoxide in bluefish from Upper Harbor. No other statistical differences were detected for the heptachlor epoxide levels. Heptachlor epoxide was highest in the brain tissues of Clarks Cove bluefish, and the heptachlor epoxide levels were followed in the decreasing order by liver, stomach, epaxial muscle and hypaxial muscle. Heptachlor epoxide in brain tissue was significantly different and greater than heptachlor epoxide in hypaxial and epaxial muscle tissues. No other tissue-specific statistical differences were detected. Heptachlor epoxide correlated with lipids in brain $(r=0.63)$ and epaxial muscle $(r=0.33)$, however it correlated poorly with weight for bluefish from Buzzards Bay $(r=0.156)$, Lower Harbor $(r=0.29)$, and Upper Harbor $(r=0.131)$. This pesticide correlated well with weight for bluefish from Clarks Cove $(r=0.689)$ and Outer Harbor $(r=0.808)$.

\subsection{Endosulfan sulfate}

Endosulfan sulfate in bluefish from Upper Harbor ranged from 0.014 to $0.15 \mathrm{ppm}$ with an average of $0.082 \mathrm{ppm}$. It ranged from 0.007 to $0.17 \mathrm{ppm}$ in bluefish from Lower Harbor with an average of $0.042 \mathrm{ppm}$, and for the Outer Harbor samples it ranged from 0.016 to $0.066 \mathrm{ppm}$ with an average of $0.042 \mathrm{ppm}$. Endosulfan sulfate was lowest in bluefish from Clarks Cove and in bluefish from
Buzzards Bay with averages of 0.004 ppm and $0.002 \mathrm{ppm}$, respectively. Dunn's All Pairwise Multiple Comparison Test detected significant differences between endosulfan sulfate in bluefish from Buzzards Bay and endosulfan sulfate in bluefish from Upper Harbor, Lower Harbor, and Outer Harbor locations. Endosulfan sulfate in bluefish from Clarks Cove was also significantly different than endosulfan sulfate in bluefish caught from Upper Harbor. No other statistical differences were detected for the endosulfan sulfate levels. Endosulfan sulfate in liver tissues of Clarks Cove bluefish were generally the greatest, and the concentrations were followed in the decreasing order by brain, stomach, hypaxial muscle, and epaxial muscle. Despite the numerical differences, no statistically significant differences were detected in the Tukey All Pairwise Multiple Comparison Test. Endosulfan sulfate correlated with lipids in liver $(r=0.65)$ and stomach $(r-0.68)$. Endosulfan sulfate correlated poorly with weight for bluefish from Clarks Cove $(r=0.05)$, Lower Harbor $(r=0.3)$, and Upper Harbor $(r=0.22)$. This pesticide correlated moderately with weight for bluefish from Clarks Cove $(r=0.649)$, and well for bluefish from Outer Harbor $(r=0.859)$.

\section{8. $\alpha$-Chlordane}

$\alpha$-Chlordane in YOY bluefish from Upper Harbor ranged from 0.01 to $0.12 \mathrm{ppm}$ with an average of $0.06 \mathrm{ppm}$. This pesticide ranged from 0.006 to $0.12 \mathrm{ppm}$ in bluefish from Lower Harbor with an average of $0.03 \mathrm{ppm}$. It ranged from 0.01 to $0.037 \mathrm{ppm}$ for Outer Harbor samples with an average of $0.021 \mathrm{ppm}$. $\alpha$-Chlordane was 
Table 4

Organochlorine pesticides in the tissues of YOY bluefish from Clarks Cove, $\mathrm{mg} / \mathrm{kg}$ wet weight (ppm).

\begin{tabular}{|c|c|c|c|c|c|c|c|c|c|c|}
\hline \multirow{2}{*}{$\begin{array}{l}\text { Tissue } \\
\text { No. of samples } \\
\text { Statistics }\end{array}$} & \multicolumn{2}{|l|}{$\begin{array}{l}\text { Brain } \\
(n=5)\end{array}$} & \multicolumn{2}{|l|}{$\begin{array}{l}\text { Liver } \\
(n=5)\end{array}$} & \multicolumn{2}{|c|}{$\begin{array}{l}\text { Stomach } \\
(n=5)\end{array}$} & \multicolumn{2}{|c|}{$\begin{array}{l}\text { Epaxial muscle } \\
(n=5)\end{array}$} & \multicolumn{2}{|c|}{$\begin{array}{l}\text { Hypaxial muscle } \\
(n=5)\end{array}$} \\
\hline & Mean & SD & Mean & SD & Mean & SD & Mean & SD & Mean & SD \\
\hline Weight & 0.099 & 0.017 & 0.431 & 0.122 & 1.594 & 0.700 & 7.711 & 2.862 & 6.113 & 1.694 \\
\hline \% Lipids & 12.89 & 8.97 & 6.13 & 4.39 & 3.34 & 2.93 & 1.38 & 0.73 & 2.27 & 1.43 \\
\hline $\mathrm{HCB}$ & 0.0308 & 0.0218 & 0.0102 & 0.0036 & 0.0089 & 0.0147 & 0.0028 & 0.0020 & 0.0016 & 0.0006 \\
\hline b-BHC & 0.186 & 0.120 & 0.103 & 0.0997 & 0.0380 & 0.0475 & 0.0078 & 0.0052 & 0.0095 & 0.0091 \\
\hline Lindane & 0.0268 & 0.0129 & 0.0139 & 0.0111 & 0.0049 & 0.0060 & 0.0012 & 0.0004 & 0.0015 & 0.0006 \\
\hline Heptachlor & 0.0287 & 0.0190 & 0.0141 & 0.0088 & 0.0046 & 0.0032 & 0.0041 & 0.0042 & 0.0036 & 0.0053 \\
\hline Heptachlor Epoxide & 0.0312 & 0.0061 & 0.0177 & 0.0115 & 0.0057 & 0.0046 & 0.0029 & 0.0010 & 0.0029 & 0.0013 \\
\hline Oxychlordane & 0.0096 & 0.0092 & 0.0029 & NA & 0.0026 & 0.0030 & 0.0008 & 0.0002 & 0.0004 & 0.0002 \\
\hline g-Chlordane & 0.0178 & 0.0178 & 0.0049 & 0.0049 & 0.0017 & 0.0014 & 0.0006 & 0.0003 & 0.0008 & 0.0003 \\
\hline a-Chlordane & 0.0204 & 0.0124 & 0.0099 & 0.0068 & 0.0039 & 0.0046 & 0.0022 & 0.0014 & 0.0019 & 0.0005 \\
\hline t-Nonachlor & 0.0156 & 0.0107 & 0.0078 & 0.0062 & 0.0022 & 0.0018 & 0.0016 & 0.0007 & 0.0015 & 0.0005 \\
\hline Endrin & nd & nd & nd & nd & nd & nd & nd & nd & nd & nd \\
\hline Endosulfan I & 0.102 & 0.0960 & 0.101 & 0.0516 & 0.0296 & 0.0143 & 0.0343 & 0.0361 & 0.0339 & 0.0073 \\
\hline Endosulfan II & 0.0134 & 0.0120 & 0.0039 & 0.0014 & 0.0036 & 0.0029 & 0.0020 & 0.0008 & 0.0031 & NA \\
\hline Endosulfan Sulfate & 0.0076 & 0.0025 & 0.0102 & 0.0063 & 0.0022 & 0.0013 & 0.0019 & 0.0009 & 0.0020 & 0.0008 \\
\hline$o, \mathrm{p}^{\prime}-\mathrm{DDE}$ & 0.0471 & 0.0377 & 0.0422 & 0.0241 & 0.0117 & 0.0062 & 0.0110 & 0.0082 & 0.0087 & 0.0021 \\
\hline $\mathrm{p}, \mathrm{p}^{\prime}-\mathrm{DDE}$ & 0.0511 & 0.0264 & 0.0365 & 0.0207 & 0.0118 & 0.0067 & 0.0102 & 0.0090 & 0.0128 & 0.0041 \\
\hline $0, \mathrm{p}^{\prime}-\mathrm{DDD}$ & 0.0517 & 0.0419 & 0.0339 & 0.0227 & 0.0086 & 0.0068 & 0.0065 & 0.0044 & 0.0069 & 0.0031 \\
\hline $\mathrm{o}, \mathrm{p}^{\prime}-\mathrm{DDT}$ & 0.0315 & 0.0417 & 0.0314 & 0.0263 & 0.0077 & 0.0054 & 0.0047 & 0.0029 & 0.0055 & 0.0031 \\
\hline $\mathrm{p}, \mathrm{p}^{\prime}-\mathrm{DDT}$ & 0.0354 & 0.0325 & 0.0046 & NA & 0.0031 & NA & 0.0036 & 0.0018 & 0.0006 & 0.0002 \\
\hline$\Sigma$ DDTs & 0.186 & 0.167 & 0.128 & 0.0819 & 0.0381 & 0.0255 & 0.0301 & 0.0251 & 0.0343 & 0.010 \\
\hline$\Sigma$ chlordanes & 0.0401 & 0.0284 & 0.0216 & 0.0162 & 0.0078 & 0.0077 & 0.0038 & 0.0020 & 0.0041 & 0.0011 \\
\hline$\Sigma$ DDTs/g lipid & 4.76 & 8.26 & 7.44 & 11.2 & 4.53 & 7.06 & 3.69 & 3.70 & 13.8 & 28.2 \\
\hline$\Sigma$ chlordanes/g lipid & 0.860 & 1.26 & 1.11 & 1.50 & 0.764 & 1.09 & 0.57 & 0.72 & 1.86 & 3.84 \\
\hline
\end{tabular}

nd $=$ not detected in sample.

$\mathrm{NA}=$ pesticide analyte was detected in only one of five samples.

Table 5

Sum of PCB congeners in YOY bluefish within and near New Bedord Harbor, $\mathrm{mg} / \mathrm{kg}$ wet weight $(\mathrm{ppm})$.

\begin{tabular}{|c|c|c|c|c|}
\hline $\begin{array}{l}\text { Upper Harbor } \\
(n=8)\end{array}$ & $\begin{array}{l}\text { Lower Harbor } \\
(n=18)\end{array}$ & $\begin{array}{l}\text { Outer Harbor } \\
(n=4)\end{array}$ & $\begin{array}{l}\text { Clarks Cove } \\
(n=4)\end{array}$ & $\begin{array}{l}\text { Buzzards Bay } \\
(n=15)\end{array}$ \\
\hline 17.0 & 16.2 & 22.0 & 1.02 & 0.264 \\
\hline 16.4 & 12.6 & 7.03 & 0.330 & 2.27 \\
\hline 8.64 & 4.23 & 11.0 & 1.17 & 0.053 \\
\hline 91.4 & 12.0 & 17.0 & 0.968 & 0.496 \\
\hline 53.4 & 6.95 & & & 0.034 \\
\hline 97.5 & 17.4 & & & 0.367 \\
\hline 59.2 & 75.3 & & & 0.298 \\
\hline \multirow[t]{11}{*}{68.6} & 10.8 & & & 0.029 \\
\hline & 14.2 & & & 0.086 \\
\hline & 92.5 & & & 0.151 \\
\hline & 11.1 & & & 0.330 \\
\hline & 26.9 & & & 0.379 \\
\hline & 46.5 & & & 1.82 \\
\hline & 35.1 & & & 0.326 \\
\hline & 10.7 & & & 0.559 \\
\hline & 12.4 & & & \\
\hline & 9.05 & & & \\
\hline & 11.8 & & & \\
\hline
\end{tabular}

As 1 of 5 Clarks Cove bluefish carcass samples was lost during processing, only four bluefish were used for these estimates.

* PCB concentrations in Clarks Cove bluefish are estimated values based on tissue concentrations.

lowest in bluefish from Clarks Cove and bluefish from Buzzards Bay with averages of $0.003 \mathrm{ppm}$ and $0.001 \mathrm{ppm}$, respectively. Dunn's All Pairwise Multiple Comparison Test detected significant differences between $\alpha$-chlordane in bluefish from Buzzards Bay and $\alpha$ chlordane in bluefish from Upper Harbor, Lower Harbor, and Outer Harbor locations. $\alpha$-Chlordane in bluefish from Clarks Cove was also significantly different than $\alpha$-chlordane in bluefish caught from Upper Harbor. No other statistical differences were detected for the $\alpha$-chlordane levels. $\alpha$-Chlordane levels were highest in the brain tissues of Clarks Cove bluefish, and the $\alpha$-chlordane levels were followed in the decreasing order by liver, stomach, hypaxial muscle and epaxial muscle. $\alpha$-Chlordane levels in brain tissue were significantly different and greater than $\alpha$-chlordane levels in epaxial and hypaxial muscle samples. No other tissue-specific statistical differences were detected. $\alpha$-Chlordane correlated with lipids only in brain $(r=0.91)$. Total chlordanes correlated poorly with weight for bluefish in Buzzards Bay $(r=0.249)$, Lower Harbor $(r=0.35)$, Upper Harbor $(r=0.14)$, and Clarks Cove $(r=0.02)$. Total chlordanes correlated well with bluefish weight for Outer Harbor bluefish $(r=0.911)$.

Principal component analyses of five major pesticides suggested close groupings of bluefish from Clarks Cove and bluefish from Buzzards Bay. Pesticides in bluefish from Upper Harbor, Lower Harbor, and Outer Harbor formed a large, loose group, with some bluefish from these locations populating close to Clarks Cove and Buzzards Bay bluefish.

\section{Discussion}

\subsection{YOY bluefish condition}

Higher condition factors for bluefish from the contaminated sites, although surprising, may be indicative of the greater prey distribution and abundance at these locations, albeit presumably containing higher contaminant burdens. Indeed, the intertidal and subtidal areas of New Bedford Harbor were reported to support abundant benthic and shellfish resources that provided spawning and nursery habitat for fish (EPA, 2010). Cardoso et al. (2007) reported that sites with high levels of contamination in the Tagus estuary in the Iberian Peninsula presented a lower diversity but also the highest prey density. The authors stated that the biodiversity in a contaminated site can be impoverished compared to other less contaminated sites, but with regard to their utilization as feeding areas by birds and fishes this was not a limiting factor. The authors also stated that unhealthy areas can still perform their 


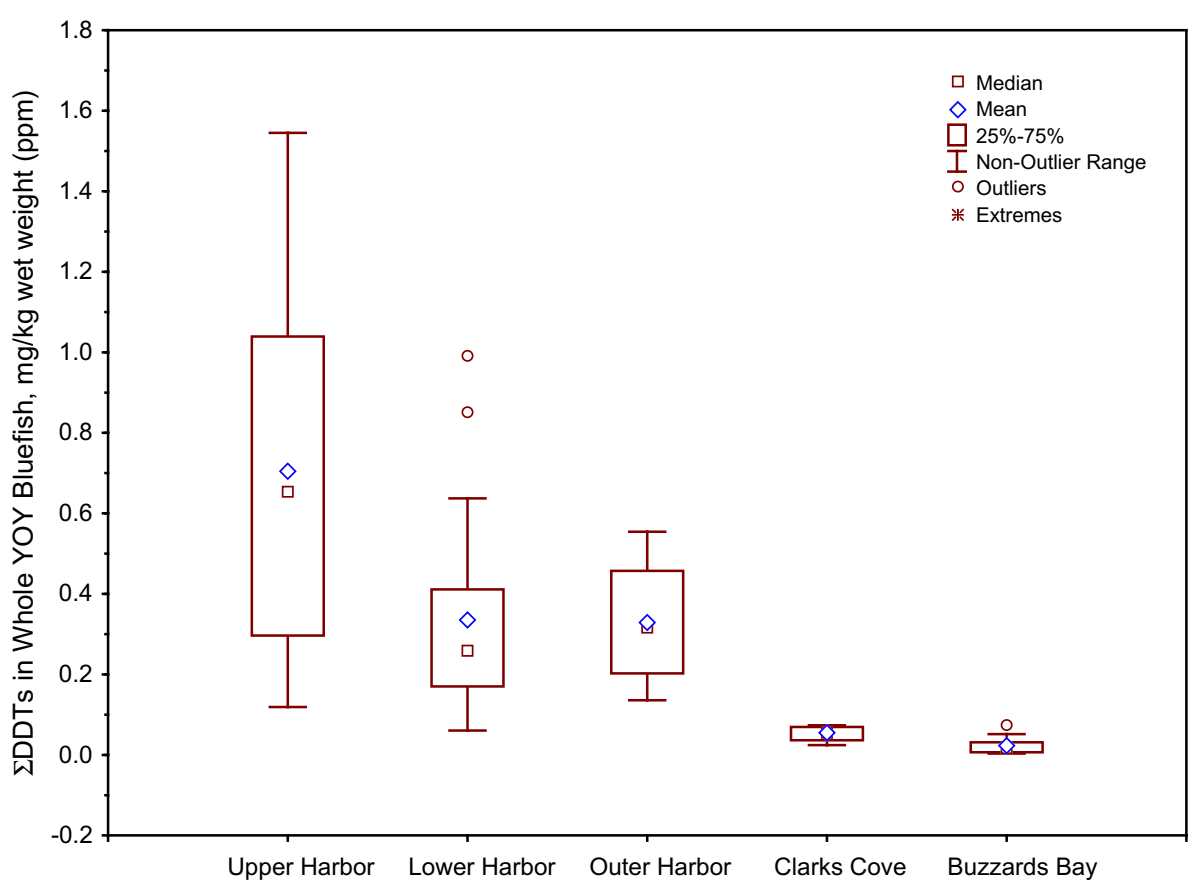

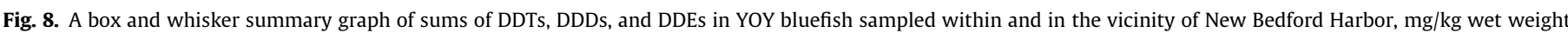

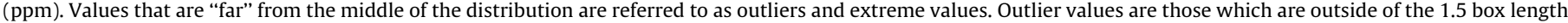
range from the upper and lower values of the box. Extreme values are those which are outside of the 3 box length range from the upper and lower values of the box.

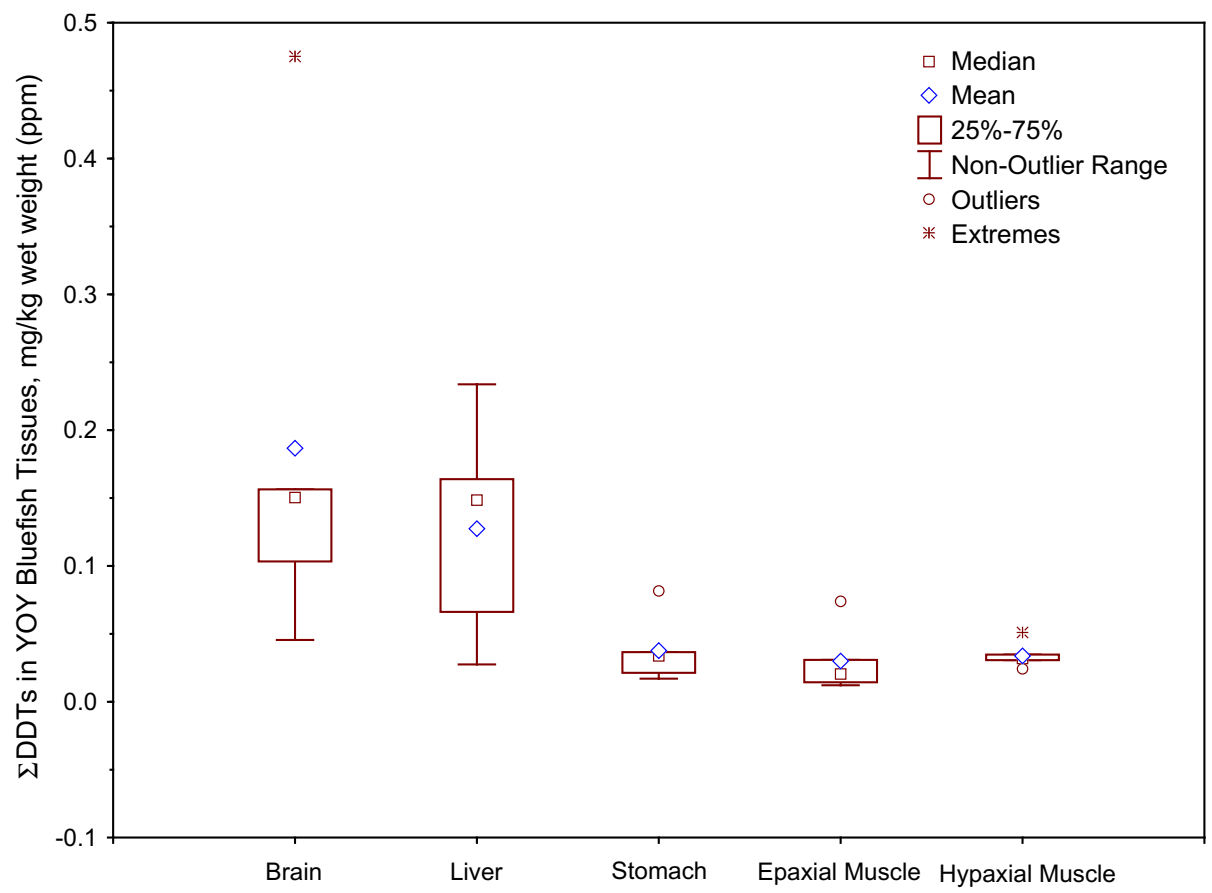

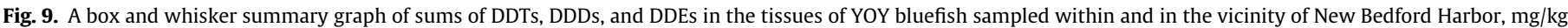

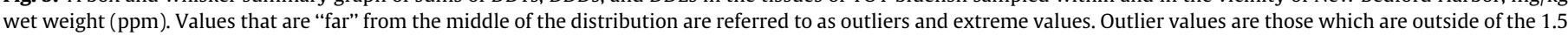

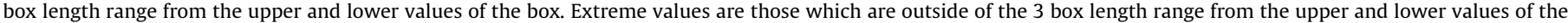
box.

ecosystem function with costs that remain to be evaluated. The YOY sampling in Buzzards Bay was conducted in early October. It was the period during which YOY and the potential prey species were possibly migrating out of the sampling area due to the decreasing sea surface temperatures. It is thus likely that YOY were not feeding at the normal levels, and in addition, they were deplet- ing their energy reserves for migration activities, finding prey, and avoiding predators. It can also be argued that the out-migrating YOY bluefish that were caught in the Buzzards Bay spent the summer in less productive habitats where they also likely had greater energetic needs avoiding the predators and finding the prey. As the predatory efficiency of less contaminated Buzzards Bay bluefish is 
likely to be higher than that of bluefish from more contaminated locations in the New Bedford Harbor (Candelmo et al., 2010), we hypothesize that differences in the abundances of the forage base could mainly account for the differences in growth and lower condition of the Buzzards Bay bluefish. The relatively smaller size could also have precluded Buzzards Bay bluefish from feeding on the larger prey species that could have also contributed to their lower condition.

\subsection{PCB contamination of YOY bluefish}

Contingent upon the prevailing sea surface temperatures, YOY bluefish recruit into the various mid- and north-U.S. Atlantic estuaries in early to late spring, and they utilize the rich resources of the nursery grounds to grow exponentially to be ready for southward migration in the fall (Shepherd and Packer, 2006). During the quest to accelerate their growth, YOY bluefish are also inadvertently exposed to different contaminants mediated via different trophic transfer vectors. Elevated PCB levels in YOY bluefish from New Bedford Harbor can probably be attributed to PCB contamination of Harbor from historical activities related to electronic component manufacturing at the former Aerovox plant, the current Superfund Site. Higher Fulton Condition Factors of YOY bluefish from contaminated sites within the Harbor (Upper Harbor, Lower Harbor, and Outer Harbor) compared to Fulton Condition Factors of Buzzards Bay bluefish suggested plentiful distribution and abundance of contaminated prey species within the Harbor. Voracious foraging of YOY bluefish on contaminated prey species could thus lead to higher contaminant burdens in bluefish within the Upper Harbor and Lower Harbor. Elevated PCB levels in bluefish from Outer Harbor can be attributed to the transport of PCBs downstream of the Acushnet Estuary due to the various geophysical transport processes, and possibly due to another source of PCB contamination related to historical electronic component manufacturing activities at the former CornellDubilier plant. A coast wide survey conducted by NOAA/EPA/FDA (1986) reported the concentrations of PCBs in the fillets of adult bluefish collected at various locations along the U.S. Atlantic coast. PCBs in bluefish collected in the vicinity of New Bedford
Harbor in that survey ranged from 3.99 to 40.6 ppm with an average of $14.7 \mathrm{ppm}$. Kolek and Ceruvels (1981) reported $16.5 \mathrm{ppm}$ of PCBs in the fillet of one bluefish sample in the Outer Harbor. PCBs in three other bluefish samples ranged from 1.0 to $1.6 \mathrm{ppm}$ with an average of $1.3 \mathrm{ppm}$. Burse et al. (1994) reported $1.33 \mathrm{ppm}$ PCBs in a composite of four samples of bluefish from Clarks Cove and $0.42 \mathrm{ppm}$ PCBs in a composite of three bluefish purchased in a seafood market in South Dartmouth, Massachusetts. High levels of PCBs, similar to those found in YOY bluefish from the New Bedford Harbor, have been reported in only a limited number of marine species like the blubber biopsies of bottlenose dolphins (Kucklick et al., 2011), harbor seals (Ross et al., 2004) and the Pacific orcas (Ross et al., 2000).

\section{3. $P C B$ congener profiles in YOY bluefish}

PCB congener profile in YOY bluefish in the Inner Harbor locations appeared to be dominated by the lighter PCB homologs, specifically the tri- and tetrachloro-homologs (Fig. 10). Until 1972, Aerovox primarily used Aroclor 1242 in the manufacture of the electrical components (Weaver, 1984). Small quantities of Aroclor 1252 and Aroclor 1254 also appeared to have been used in these operations. The use of these Aroclors was discontinued in 1972, and the electrical components were manufactured with Aroclor 1016 from 1972 to 1978. PCB congener patterns of Aroclor 1254 and Aroclor 1252 appear to be qualitatively similar due to the fairly similar chlorine weight percentages, and the PCB composition in these two Aroclor mixtures is dominated by the heavier PCB homologs. PCB congener patterns of Aroclor 1242 and Aroclor 1016 appear to be approximately similar, with a larger preponderance of monochloro-, dichloro-, trichloro-, and to smaller extent, tetrachloro-homologs. As the lighter PCB homologs are believed to be weathered relatively quickly in the aquatic environments due to the various geophysical and biogeochemical weathering processes compared to their heavier PCB homolog counterparts, the PCB congener profile in a given environmental sample is generally expected to be dominated by the heavier PCB homologs, with $\mathrm{PCB}$ 153 being one the most prominent $\mathrm{PCB}$ congeners. Despite their higher susceptibility to the weathering processes, the relative

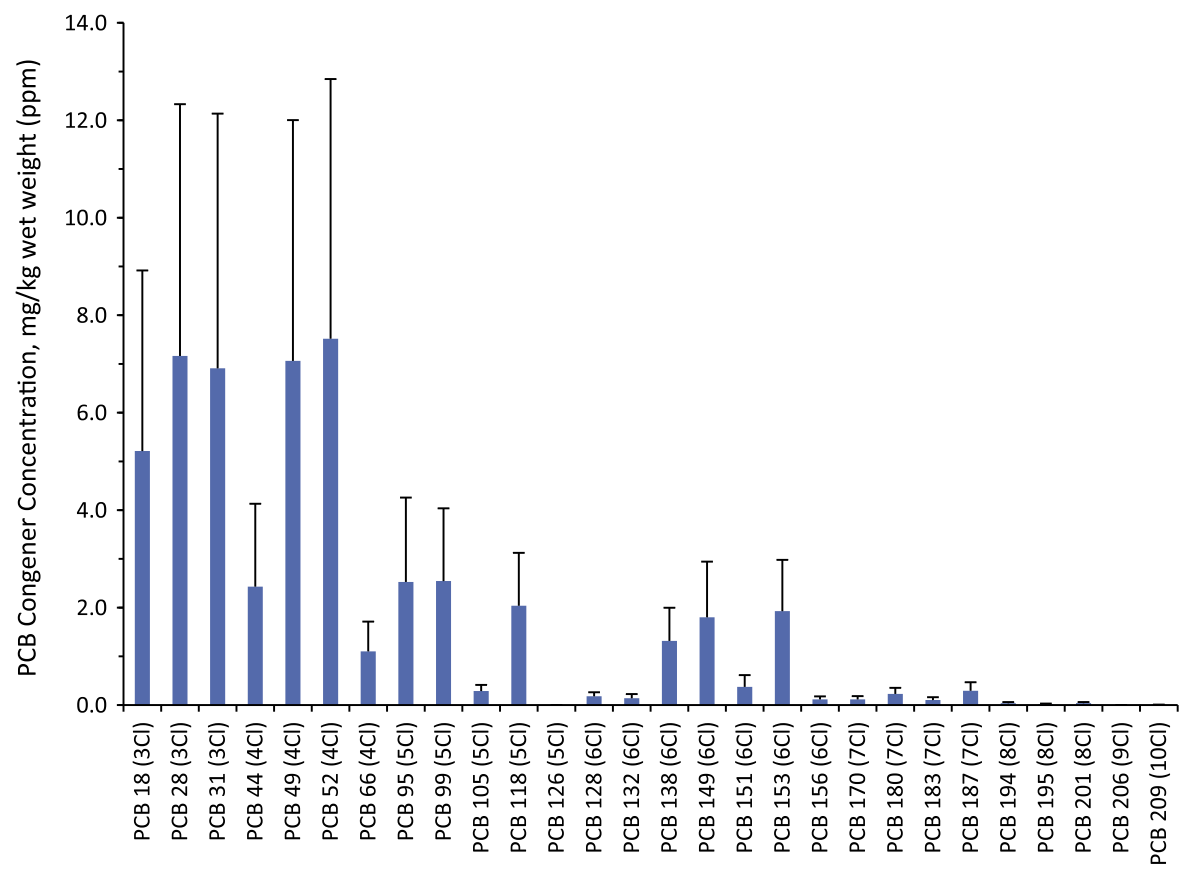

Fig. 10. A profile of PCB congener concentrations in YOY bluefish $(n=8)$ sampled in the Upper Harbor, mg/kg wet weight (ppm). 
dominance of lighter homologs in the Inner Harbor samples was surprising. The lighter PCB homologs can perhaps be related to the input of ongoing or recent sources of the lighter PCBs, particularly from those associated with sedimentary deposits of Aroclor 1242 and Aroclor 1016. The presence of heavier homologs in the Inner Harbor bluefish samples can be attributed to Aroclor 1252 and Aroclor 1254 that were being used in relatively smaller quantities in the manufacture of electrical components in addition to normal use of Aroclor 1242 and Aroclor 1016. The results of PCB congener analyses indicated that as YOY bluefish samples were collected away from the Acushnet Estuary the concentration of heavier PCB homologs increased with an increase in distance from the Superfund Site. Thus, while the lighter PCB homologs and the heavier PCB homologs were about proportionately distributed in bluefish in the Outer Harbor south of the Hurricane Barrier (Fig. 11), heavier PCB homologs appeared to dominate in various tissue samples of bluefish from Clarks Cove (Fig. 12) and in bluefish from Buzzards Bay (Fig. 13). Although, the time-frame and the proportion of PCB homologs used by Cornell-Dubilier in the Outer Harbor were approximately similar to those used by Aerovox in the

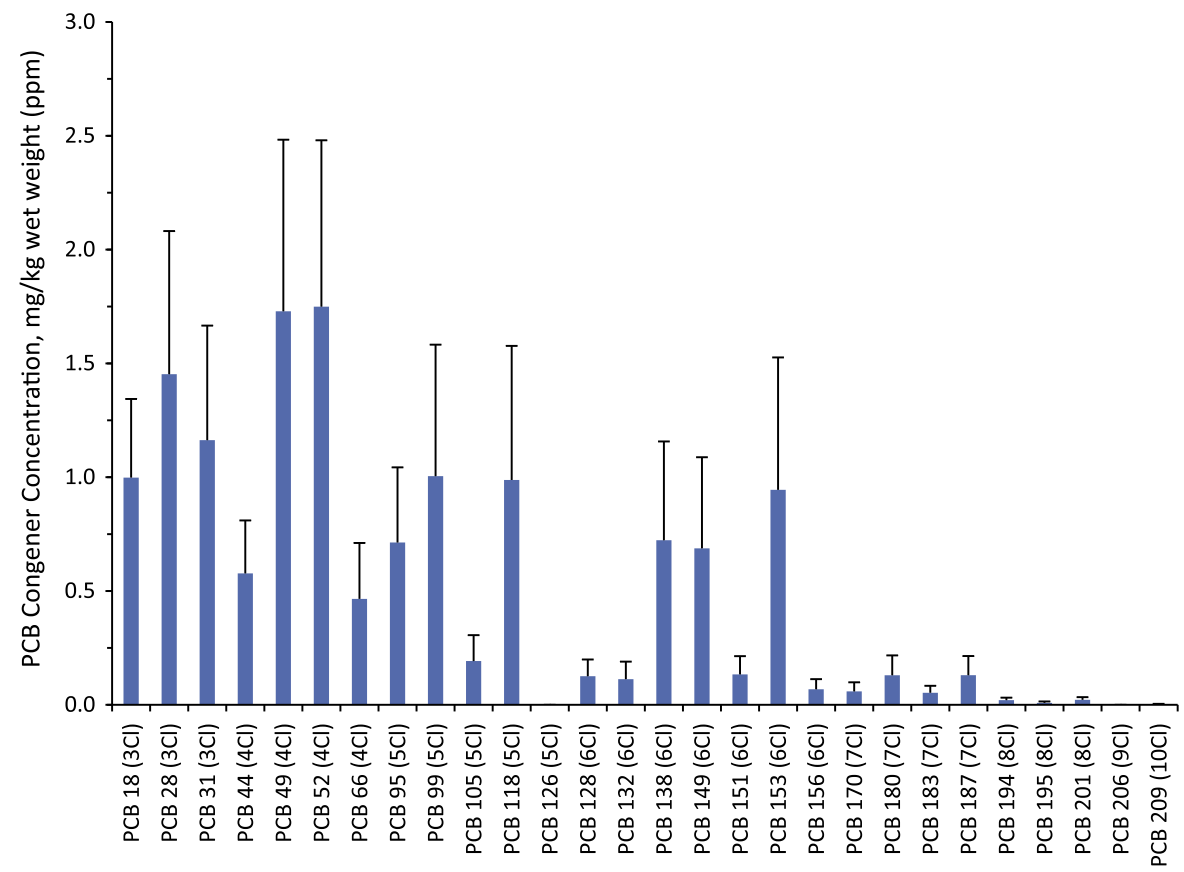

Fig. 11. A profile of PCB congener concentrations in YOY bluefish $(n=4)$ sampled in the Outer Harbor, mg/kg wet weight (ppm).

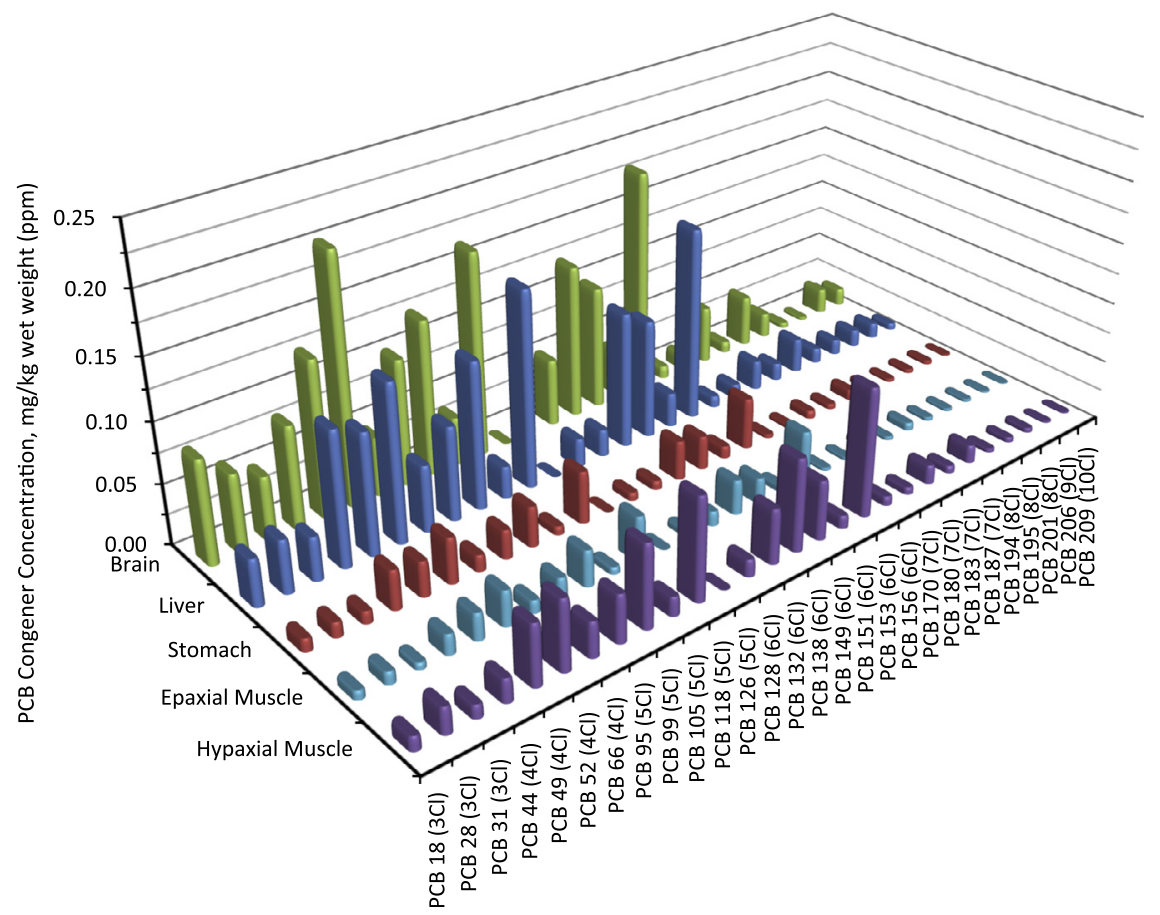

Fig. 12. Profiles of $\mathrm{PCB}$ congener concentrations in the tissue samples of YOY bluefish caught in Clarks Cove, mg/kg wet weight (ppm). 


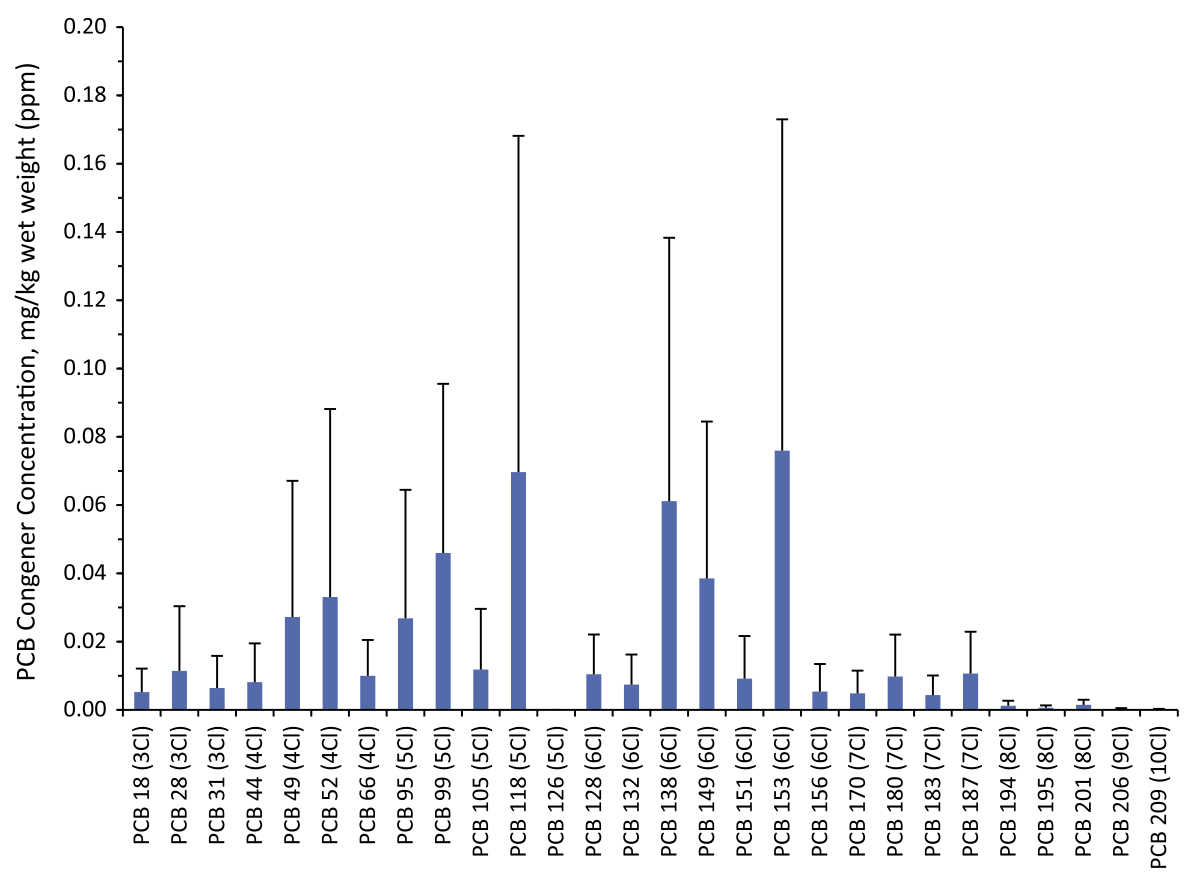

Fig. 13. A profile of $P C B$ congener concentrations in YOY bluefish sampled in the Buzzards Bay, $\mathrm{mg} / \mathrm{kg}$ wet weight (ppm).

Inner Harbor, PCBs in Outer Harbor had a better chance of dispersion and dilution due to an open interface with the Buzzards Bay, while the presence of Hurricane Barrier may have severely restricted such relatively efficient dispersal and dilution processes for the Inner Bay contaminants.

Although the PCB congener patterns in Figs. 10 and 11 suggested a gradual increase in the heavier PCB homologs in YOY bluefish as the samples were collected away from Inner Harbor to Outer Harbor, the principal component analyses suggested that PCB patterns in bluefish from Inner Harbor and Outer Harbor were statistically indistinguishable. Similar use and disposal practices of similarly natured PCB materials by Aerovox in the Inner Harbor and Cornell Dubilier in the Outer Harbor may have contributed to the observed similarities in the PCB congener patterns. Bluefish from Upper Harbor and Lower Harbor could be distinguished from bluefish from Outer Harbor based on the total PCB concentrations, but not on the basis of PCB 153 normalized PCB congener signatures. The site fidelity could not be conclusively detected in YOY bluefish from Upper Harbor, Lower Harbor, or Outer Harbor, nevertheless the greater residence of bluefish samples at the sites was apparent based on the general gradient of decreasing contaminant levels as the bluefish are collected away from the Aerovox Superfund Site. Lake et al. (1995) analyzed water, sediment, ribbed mussels, shrimp, mummichogs, and eels from different locations in the Inner Harbor. The authors reported groupings by species in the principal component analyses. However, they did not detect any groupings for a given species between different locations, which suggested a fairly uniform pattern of PCB congeners in the Inner Harbor, with the species-selective bioaccumulation kinetics for the specific PCB congeners.

The grouping of Upper Harbor and Lower Harbor bluefish in the principal component analyses graph (Fig. 7) and the presence of some highly PCB contaminated bluefish at Lower Harbor suggested intermixing and extended residences within the Upper Harbor and Lower Harbor locations, and perhaps increased probabilistic potential for their exposure to the high levels of PCBs. Bluefish in Outer Harbor grouped with Inner Harbor bluefish in the principal component analyses graph which suggested similar PCB patterns be- tween the Inner Harbor and Outer Harbor bluefish. However the consistently lower PCB levels in the Outer Harbor bluefish suggested minimal exchange between the two populations across the Hurricane Barrier.

PCB congener concentrations in different tissues of bluefish from Clarks Cove varied from tissue to tissue in a given fish and between different fish (Fig. 12). However, the PCB 153 normalized principal component analyses of PCB congeners (Fig. 7) did not identify any distinct groupings among different tissues or different fish, which suggested that despite the variation in concentration of a given PCB congener between the tissues, the PCB 153 normalized PCB patterns did not differ significantly between the tissues. A distinct, tissue-specific bioaccumulation kinetics for the PCB congener pattern was therefore assumed to be insignificant in the specimens analyzed.

\subsection{Implications of PCBs and other contaminants in the YOY bluefish}

Adverse impacts of PCBs and other chemicals in the experimental and field specimens have been well documented in the scientific literature. Examples of harmful impacts in fish include deformities, abnormal eyes, and mortalities in rainbow trout fry (Hogan and Brauhn, 1975), and the elevated levels of hepatic P4501A and EROD activity in mummichog (Gallagher et al., 1995). Examples of harmful impacts in aquatic marine mammals include negative correlations with thyroid hormone thyroxine T4 and FT4, and a positive correlation with the level of thyroid hormone receptor-alpha gene expression TR- $\alpha$ mRNA in harbor seals from Puget Sound (Tabuchi et al., 2006); negative correlations with Vitamin A and thyroid hormone triiodothyronine T3 in juvenile California sea lions (Debier et al., 2005); and anemia with elevated liver enzymes and electrolytes, elevated lactate dehydrogenases, hypermagnesemia, negative correlations with total thyroid hormones triiodothyronine TT3 and free throxine FT4, T-lymphocyte proliferative response, and negative correlations with neutrophil and monocyte phagocytosis in bottlenose dolphins in the Western North Atlantic Ocean and Northern Gulf of Mexico (Schwacke et al., 2011). An example of harmful impact in terrestrial mammals 
includes LD50 in 3 months and completely inhibited reproduction in mink (Aulerich et al., 1985). In contrast, despite the high bioaccumulation of PCBs in the eggs and nestlings, the impact on reproductive success was insignificant in the tree swallows (Jayaraman et al., 2009). Examples of adaptive resistance to chemical contaminants include mummichog from Newark Bay (Prince and Cooper, 1995), New Bedford Harbor (Nacci et al., 1999, 2010), and Elizabeth River (Van Veld and Westbrook, 1995; Ownby et al., 2002). An example of evolutionary resistance includes a heritable six-base deletion in the AHR2-1 allele leading to 100-fold lower sensitivity of CYP1A expression to induction in the Hudson River tomcod (Wirgin et al., 2011). Wirgin et al. wrote that the resistance is believed to be accompanied by evolutionary costs that are manifest either as heightened sensitivity to other stressors or impaired performance in common life history traits (Van Straalen and Hoffmann, 2000).

In a bluefish-specific, laboratory feeding exposure study in our laboratory, Candelmo et al. (2010) reported that the YOY bluefish fed with prey from the contaminated Hackensack River, New Jersey bioaccumulated significantly elevated concentrations of PCBs, pesticides, and total mercury compared to the bluefish fed with prey from a reference site in relatively uncontaminated Tuckerton, New Jersey. It was observed that YOY bluefish fed with contaminated prey displayed significantly altered behavior that resulted in reduced feeding, reduced spontaneous activity, and reduced growth compared to YOY bluefish fed with prey from the remote, relatively uncontaminated reference site. The reduced growth would affect the condition of YOY bluefish which can compromise their migratory competence, decrease their ability to be efficient predators, increase their own susceptibility to predation, and lessen their likelihood of contributing to the adult bluefish stock. Increased exposure to PCBs can also cause several other unquantified deleterious effects, including neurobehavioral effects, endocrine effects, and reproductive effects.

The widespread chemical contamination of Acushnet Estuary, particularly with the PCBs, prompted the Massachusetts Department of Public Health to close the vital and lucrative shellfish, finfish, and lobster fisheries in order to protect the human health (Kolek and Ceruvels, 1981). The "Hot Spot" remediation removed sediments with PCB concentrations greater than $4000 \mathrm{ppm}$ and was completed in the fall of 1995 (Nelson and Bergen, 2012; Bergen et al., 2005). The Superfund Site is currently being extensively remediated, and the overall goals of the project are to: (a) reduce the health risks due to the consumption of PCB-contaminated local seafood, (b) reduce the health risks due to contact with the PCBcontaminated shoreline sediments, and (c) improve the quality of the Harbor's highly degraded marine ecosystem (EPA ROD, 1998). Although the ecological risk assessment suggests a $0.1-1.0 \mathrm{ppm}$ sediment PCB threshold for the protection of marine organisms, EPA stated that this remediation effort would require the removal or capping of massive amounts (2.1 million cubic yards) of contaminated sediments spread over approximately 1000 acres. In addition, EPA stated that achieving this target cleanup level (TCL) could potentially cause more ecological harm than good due to radical alterations to the harbor, destruction of valuable salt marsh habitat, loss of aquatic habitat due to disposal facilities, extreme amounts of dredging or capping, enormous volumes of contaminated sediments, disposal space limitations, cost, and adverse environmental impacts that would result given the widespread nature of the PCB contamination (EPA ROD, 1998). Thus sediment TCLs of 10,50 and 500 ppm PCBs, as well as a no-action alternative were thought to establish more realistic and less damaging categories of cleanup alternatives. Numerical models suggested that Hot-Spot and $500 \mathrm{ppm}$ remediation scenarios were not significantly different from the No-Action case (Battelle, 1991). This model suggested that the removal of hot spots in the Upper Estuary between Slocum
Street/Wood Street Bridge and Coggeshall Street Bridge may not lead to significant reductions in water column and sediment PCB concentrations in the Lower Harbor. The numerical model suggested that target sediment PCBs at $1 \mathrm{ppm}$ would result in the greatest reduction of PCBs from Slocum Street/Wood Street Bridge to Hurricane Barrier. Remediation of sediments to 1-10 ppm was a suggested alternative. Another alternative was remediation of sediments containing $50 \mathrm{ppm}$ or greater PCBs between Slocum Street/ Wood Street Bridge and Hurricane Barrier to 1-10 ppm. NOAA supported the hybrid TCL approach due to the logistic problem of moving below $10 \mathrm{ppm}$. NOAA also recognized the objective of using a $50 \mathrm{ppm}$ TCL to minimize the amount of salt marsh destruction, but expressed concern that a $50 \mathrm{ppm}$ TCL would not necessarily protect biota that use the salt marsh. EPA modified the proposed remedy to include a $10 \mathrm{ppm}$ sediment $\mathrm{PCB}$ cleanup in the upper Harbor north of Coggeshall Street. EPA also proposed to dredge the sediments above $50 \mathrm{ppm}$ in the Lower Harbor and in salt marshes. EPA noted that the risks due to PCB exposure to the biota will vary depending on the migratory behavior or lack thereof, foraging behavior, and prey preferences of each species (EPA ROD, 1998). EPA also noted that juvenile aquatic organisms using the upper harbor area as a nursery ground may be at an elevated risk given that this life stage is generally more sensitive to chemical insult than the adult stage.

Given the widespread contamination of PCBs and other contaminants, complex, pragmatic, and cost-effective nature of Superfund Site remediation plan, along with bioaccumulation of high concentrations of PCBs in deployed mussels (Nelson and Bergen, 2012), bioaccumulation of PCBs in resident species like mummichog (Nacci et al., 2010), bioaccumulation of PCBs in migratory fish such as YOY bluefish (this study) and adult bluefish (NOAA/FDA/EPA 1986), trophic transport of PCBs to eggs and nestlings of aerial species like insectivorous tree swallow (Jayaraman et al., 2009), and the expectation that remediation efforts using the current compromised criteria would continue to proceed for more than 20 years (Nelson and Bergen, 2012), it can be argued that the PCBs or other contaminants may likely never be completely removed from the New Bedford Harbor. The ongoing remediation efforts in mitigating the PCB contamination are certainly highly commendable and enormously environmentally beneficial. The question on functional ecological benefits, and the question on cumulative and synergistic impacts of chronic exposure to the residual PCBs and other legacy contaminants, albeit the comprehensive but compromised and protracted remediation, on the health, resiliency, and reproduction of the resident and migratory fisheries stocks remains to be investigated, and it may likely remain elusive. Although the feeding exposure studies of Candelmo et al. (2010) clearly demonstrated the harmful behavioral impacts of PCBs and other contaminants in the experimental YOY bluefish, the harmful effects and the adaptive or evolutionary resistance to the deleterious synergy of PCBs and various contaminants in New Bedford Harbor on the migrating feral specimens of bluefish needs to be investigated. The contribution of New Bedford Harbor YOY bluefish to the adult population also needs to be examined in future studies to understand the role of contaminated habitats in sustaining a healthy stock of this important fishery. The data presented in this article will provide a reference baseline for YOY bluefish to help undertake future "before-and-after" comparative studies after the mandated Superfund Site remediation operation has been completed.

\section{Acknowledgements}

We thank Jeremy King at the Massachusetts Division of Marine Fisheries for the generous donation of Buzzards Bay bluefish samples. The observation of the relatively elevated PCBs in the two Buzzards Bay specimens actually formed the basis for the present 
study. We thank Ken Finkelstein at the NOAA Office of Response and Restoration, Dianne Nacci and William Nelson at the Environmental Protection Agency, Jennifer Samson and Andrew F. J. Draxler (retired) at the NOAA Fisheries, Jeremy King, Vincent Malkoski, and Paul Craffey at the Massachusetts Division of Marine Fisheries, and the unknown reviewer of this journal for their critical readings and helpful suggestions in the preparation of this manuscript.

\section{References}

Aulerich, R., Bursian, S., Breslin, W., Olsen, B., Ringer, R.K., 1985. Toxicological manifestation of $2,2^{\prime}, 4,4^{\prime}, 5,5^{\prime}$ and $2,2^{\prime}, 3,3^{\prime}, 6,6^{\prime}$, and $3,3^{\prime}, 4,4^{\prime}, 5,5^{\prime}-$ hexachlorobiphenyl and Aroclor 1254 in mink. J. Toxicol. Environ. Health 15, 63-79.

Ballschmiter, K., Zell, M., 1980. Analysis of polychlorinated biphenyls (PCB) by glass capillary gas chromatography. Fresenius' J. Anal. Chem. 302, 20-31.

Battelle, 1991. A Report on Overview of the New Bedford Harbor Physical/Chemical Modeling Program. Prepared by Battelle Ocean Sciences, Duxbury, Massachusetts for Ebasco Services, Inc., Boston, Massachusetts. SDMS DocID 282896. April 1, 1991. <http://www.epa.gov/region1/superfund/sites/ newbedford/282896.pdf>.

Bergen, B.J., Nelson, W.G., Mackay, J., Dickerson, D., Jayaraman, S., 2005 Environmental monitoring of remedial dredging at the New Bedford Harbor, MA, Superfund Site. Environ. Monit. Assess. 111, 257-275.

Burse, V.W., Groce, D.F., Caudill, S.P., Korver, M.P., Phillips, D.L., McClure, P.C., Lapeza Jr., C.R., Lapeza, S.L., Miller, D.T., Buckley, D.J., Nassif, J., Timperi, R.J., George, P.M., 1994. Determination of polychlorinated biphenyl levels in the serum of residents and in the homogenates of seafood from the New Bedford, Massachusetts, area: a comparison of exposure sources through pattern recognition techniques. Sci. Total Environ. 144 (1-3), 153-177.

Candelmo, A., Deshpande, A.D., Dockum, B.W., Weis, P., Weis, J.S., 2010. The effect of contaminated prey on feeding, activity, and growth of young-of-the-year bluefish, Pomatomus saltatrix, in the laboratory. Estuaries Coasts 33, 1025-1038.

Cardoso, I., Granadeiro, J.P., Cabral, H.N. 2007. Benthic prey quantity and quality in the main mudflat feeding areas of the Tagus estuary: implications for bird and fish populations. ICES CM 2007/A: 28 Poster. <http://www.ices.dk/products/ AnnualRep/ASCproceedings/2007/Annual\%20Science\%20Conference\%202007/ CM-2007/A/A2807ABS.pdf $>$.

Debier, C., Ylitalo, G.M., Weise, M., Gulland, F., Costa, D.P., Le Boeuf, B.J., de Tillesse T., Larondelle, Y., 2005. PCBs and DDT in the serum of juvenile California sea lions: associations with vitamins $\mathrm{A}$ and $\mathrm{E}$ and thyroid hormones. Environ. Pollut. $134,323-332$.

Deshpande, A.D., Draxler, A.F.J., Zdanowicz, V.S., Schrock, M.E., Paulson, A.J., 2002. Contaminant levels in the muscle of four species of fish important to the recreational fishery of the New York Bight Apex. Mar. Pollut. Bull. 44, 164-177.

Deshpande, A.D., Draxler, A.F.J., Zdanowicz, V.S., Schrock, M.E., Paulson, A.J., Finneran, T.W., Sharack, B.L., Corbo, K., Arlen, L., Leimburg, E., Dockum, B.W. Pikanowski, R.A., May, B., Rosman, L., 2000. Contaminant levels in muscle of four species of recreational fish from the New York Bight apex. NOAA Tech. Memo. NMFS-NE-157, 99 p.

Ellerby, D.J., Altringham, J.D., 2001. Spatial variation in fast muscle function of the rainbow trout Oncorhynchus mykiss during fast-starts and sprinting. J. Exp. Biology 204, 2239-2250.

EPA, 1993. Laboratory methods manual estuaries. EPA Doc. 600/4-91/024; 289 p. EPA Office of Research and Development, Cincinnati, OH.

EPA ROD, 1998. Declaration for the Record of Decision (ROD). New Bedford Harbor Superfund Site Upper and Lower Harbor Operable Unit. New Bedford Massachusetts. U.S. Environmental Protection Agency - Region I. New England09-25-1998, SDMS\# 38206, September 1998.

EPA, 2008. Framework for Application of the Toxicity Equivalence Methodology for Polychlorinated Dioxins, Furans, and Biphenyls in Ecological Risk Assessment Office of the Science Advisor, Risk Assessment Forum, U.S. Environmental Protection Agency, Washington, DC 20460, EPA/100/R-08/004, June 2008.

EPA, 2010. Biological Assessment for the New Bedford Harbor - South Terminal Project, New Bedford, Massachusetts. Prepared by U.S. Army Corps of Engineers, New England District, Environmental Resources Section. Prepared for U.S Environmental Protection Agency, Office of Ecosystem Protection, U.S. EPA New England Region, October 2010, 32 pp. <http://www.epa.gov/region1/superfund/ sites/newbedford/518530.pdf>

EPA, 2011. Fourth Explanation of Significant Differences for Use of a Lower Harbor Cad Cell (LHCC) New Bedford Harbor Superfund Site Operable Unit \#1 New Bedford, Massachusetts. U.S. Environmental Protection Agency - Region I. New England. March 2011, 89 pp. <http://www.epa.gov/region1/superfund/sites/ newbedford/479471.pdf>

New Bedford Harbor Fish Consumption Regulations and Recommendations. <http:/ www.epa.gov/region1/superfund/sites/newbedford/504376.pdf>

FDA, 1991. Tolerances of Polychlorinated Biphenyls (PCBs), 21 CFR Ch. 1, April 1, 1991, Sect 109.30(a)(7), U.S. Food and Drug Administration. Health Human Services, Public Health Service, Rockville, MD, pp. 96-98.

Falconer, R.L., Bidleman, T.F., 1994. Vapor pressures and predicted particle/gas distributions of polychlorinated biphenyl congeners as functions of temperature and ortho-chlorine substitution. Atmos. Environ. 28 (3), 547-554.
Gallagher, K., Van Veld, P.A., Hale, R.C., Stegeman, J.J., 1995. Induction of cytochrome $\mathrm{P} 4501 \mathrm{~A}$ in the mummichog (Fundulus heteroclitus) by the polychlorinated terphenyl formulation Aroclor 5432. Environ. Toxicol. Chem. 14, 405-409.

Hogan, J.W., Brauhn, J.L., 1975. Abnormal rainbow trout fry from eggs containing high residues of a PCB (Aroclor 1242). Prog. Fish-Cult. 37, 229-230.

Jayne, B.C., Lauder, G.V., 1995. Speed effects on midline kinematics during steady undulatory Swimming of largemouth bass, Micropterus salmoides. J. Exp. Biol. $198,585-602$.

Jayaraman, S., Nacci, D.E., Champlin, D.M., Pruell, R.J., Rocha, K.J., Custer, C.M., Custer, T.W., Cantwell, M., 2009. PCBs and DDE in Tree Swallow (Tachycineta bicolor) Eggs and Nestlings from an Estuarine PCB Superfund Site, New Bedford Harbor, MA, U.S.A.. Environ. Sci. Tech. 43 (21), 8387-8392.

Johnson, L.L., Stehr, C.M., Olson, O.P., Myers, M.S., Pierce, S.M., McCain, B.B., Varanasi, U., 1992. National Benthic Surveillance Project: Northeast Coast Fish Histopathology and Relationships Between Lesions and Chemical Contaminants (1987-89). NOAA Technical, Memorandum NMFS-NWFSC-4, December 1992.

Kimbrough, K.L., Johnson, W.E., Lauenstein, G.G., Christensen, J.D., Apeti, D.A., 2008. An Assessment of Two Decades of Contaminant Monitoring in the Nation's Coastal Zone, Silver Spring, MD, NOAA Technical Memorandum NOS NCCOS 74, 105 pp.

Kolek, A., Ceruvels, R. 1981. PCB analysis of marine organisms in the New Bedford area 1976-1980 (Pub. No. 12265-36-100-1-81-CR), Commonwealth of Massachusetts, Division of Marine Fisheries, Boston, MA

Krahn, M.M., Wigren, C.A., Pearce, R.W., Moore, L.K., Bogar, R.G., MacLeod, W.D., Jr., Chan, S.-L., Brown, D.W. 1988. Standard analytical procedures of the NOAA National Analytical Facility, 1988: new HPLC cleanup and revised extraction procedures for organic contaminants, NOAA Tech Memo, NMFS FNWC-153, 52

Kucklick, J., Schwacke, L., Wells, R., Hohn, A., Guichard, A., Yordy, J., Hansen, L., Zolman, E., Wilson, R., Litz, J., Nowacek, D., Rowles, T., Pugh, R., Balmer, B., Sinclair, C., Rosel, P., 2011. Bottlenose Dolphins as Indicators of Persistent Organic Pollutants in the Western North Atlantic Ocean and Northern Gulf of Mexico. Environ. Sci. Technol. 45, 4270-4277.

Kusakabe, R., Kuratani, S., 2005. Evolution and developmental patterning of the vertebrate skeletal muscles: perspectives from the lamprey. Dev. Dyn. 234, 824-834.

Lake, J.L., McKinney, R., Lake, C.A., Osterman, F.A., Heltshe, J., 1995. Comparisons of patterns of polychlorinated biphenyl congeners in water, sediment, and indigenous organisms from New Bedford Harbor, Massachusetts. Arch. Environ. Contam. Toxicol. 29, 207-220.

MSCD, 2012. Metropolitan State University of Denver. <http://rowdy.mscd.edu/ haysc/public_html/bio322/Welcome322.htm.htm>.

Nacci, D., Coiro, L., Champlin, D., Jayaraman, S., McKinney, R., Gleason, T.R., Munns, W.R., Specker, J.L., Cooper, K.R., 1999. Adaptations of wild populations to the estuarine fish Fundulus heteroclitus to persistent environmental contaminants. Mar. Biol. 134, 9-17.

Nacci, D.E., Champlin, D., Jayaraman, S., 2010. Adaptation of the Estuarine Fish Fundulus heteroclitus (Atlantic Killifish) to Polychlorinated Biphenyls (PCBs). Estuaries Coasts 33 (4), 853-864.

Nakajoh, K., Shibata, E., Todoroki, T., Ohara, A., Nishizawa, K., Nakamura, T., 2005. Vapor pressure of ten polychlorinated biphenyl congeners and two commercial fluids as a function of temperature. Environ. Toxicol. Chem. 24 (7), 1602-1608.

Nelson, W.G., Bergen, B.J., Benyi, S.J., Morrison, G., Voyer, R.A., Strobel, C.J., Rego, S., Thursby, G., Pesch, C.E., 1996. New Bedford Harbor longterm monitoring and assessment report: Baseline sampling. US Environmental Protection Agency, National Health and Environmental Effects Research Laboratory, Atlantic Ecology Division, Narragansett, RI, EPA/600/R-96/097.

Nelson, W.G., Bergen, B.J., 2012. The New Bedford Harbor Superfund Site long-term monitoring program (1993-2009). Environ. Monit. Assess. 184, 7531-7550.

Newell, A.J., Johnson, D.W., Allen, L.K., 1987. Niagara River Biota Contamination Project: Fish Flesh Criteria for Piscivorous Wildlife. Technical Report 87-3. New York State Department of Environmental Conservation Division of Fish and Wildlife, Bureau of Environmental Protection, Albany, New York. July 1987 (Reprinted February 2000).

NOAA/FDA/EPA, 1986. Report on 1984-86 Federal Survey of PCBs in Atlantic Coast Bluefish. Data Report. National Oceanic and Atmospheric Administration, Food and Drug Administration, Environmental Protection Agency, April 1986.

NOAA, 1989. A summary of data on tissue contamination from the first three years (1986-1988) of the Mussel Watch Program. NOAA Tech. Memo. NOS OMA 49, $154 \mathrm{p}$

Ownby, D.R., Newman, M.C., Mulvey, M., Vogelbein, W.K., Unger, M.A., Arzayus, L.F., 2002. Fish (Fundulus heteroclitus) populations with different exposure histories differ in tolerance of creosote-contaminated sediments. Environ. Toxicol. Chem. 21, 1897-1902.

Pesch, C.E., Voyer, R.A., Latimer, J.S., Copeland, J., Morrison, G., McGovern, D. 2011. Imprint of the Past: Ecological History of New Bedford Harbor. http:// www.epa.gov/nbh/pdfs/ImprintOfThePast.pdf.

Prince, R., Cooper, K.R., 1995. Comparisons of the effects of 2,3,7,8teterachlorodibenzo-p-dioxin on chemically impacted and nonimpacted subpopulations of Fundulus heteroclitus. I. TCDD toxicity. Environ. Toxicol. Chem. 14, 579-588.

Ricker, W.E., 1975. Computation and interpretation of the biological statistics of fish populations. Bull. Fish. Res. Bd. Can. Ottawa 191, 1-382.

Ross, P.S., Ellis, G.M., Ikonomou, M.G., Barrett-Lennard, L.G., Addison, R.F., 2000. High PCB Concentrations in free-ranging pacific killer whales, Orcinus orca: effects of age, sex and dietary preference. Mar. Pollut. Bull. 40 (6), 504-515. 
164

A.D. Deshpande et al./Marine Pollution Bulletin 72 (2013) 146-164

Ross, P.S., Jeffries, S.J., Yunker, M.B., Addison, R.F., Ikonomou, M.G., Calambokidis, J., 2004. Harbour seals (Phoca vitulina) in British Columbia, Canada, and Washington State, USA, reveal a combination of local and global polychlorinated biphenyl, dioxin, and furan signals. Environ. Toxicol. Chem. 23, 157-165.

Schwacke, L., Zolman, E., Balmer, B., De Guse, S., George, R., Hoguet, J., Hohn, A., Kucklick, J., Lamb, S., Levin, M., Litz, J., McFee, W., Place, N., Townsend, F., Wells, R., Rowles, T. 2011. Anemia, hypothyroidism and immune suppression associated with polychlorinated biphenyl exposure in bottlenose dolphins (Tursiops truncatus). Proc. R. Soc. B. 11 pp plus supplement.

Shepherd, G.R. Packer, D.B. 2006. Essential Fish Habitat Source Document: Bluefish, Pomatomus saltatrix, Life History and Habitat Characteristics. second ed. NOAA Tech. Memo. NMFS-NE-198. June 2006.

Sloan, C.A., Adams, N.G., Pearce, R.W., Brown, D.W., Chan, S.-L. 1993. Northwest Fisheries Science Center organic analytical procedures. In: Lauenstein, G.G. Cantillo, A.Y., eds. Sampling and analytical methods of the National Status and Trends Program, National Benthic Surveillance and Mussel Watch Projects, 1984-1992. vol. 4. Comprehensive descriptions of trace organic analytical methods. NOAA Tech. Memo. NOS ORCA 71, $182 \mathrm{p}$.

Tabuchi, M., Veldhoen, N., Dangerfield, N., Jeffries, S., Helbing, C.C., Ross, P.S., 2006. PCB-related alteration of thyroid hormones and thyroid hormone receptor gene expression in free-ranging harbor seals (Phoca vitulina). Environ. Health Perspect. 114, 1024-1031.

Thys, T., 1997. Spatial variation in epaxial muscle activity during prey strike in largemouth bass (Micropterus salmoides). J. Exp. Biol. 200, 3021-3031.
Van den Berg, M., Birnbaum, L., Bosveld, A.T.C., Brunstrom, B., Cook, P., Feeley, M., Giesy, J.P., Hanberg, A., Hasegawa, R., Kennedy, S.W., Kubiak, T., Larsen, J.C., van Leeuwen, F.X., Liem, A.K., Nolt, C., Peterson, R.E., Poellinger, L., Safe, S., Schrenk, D., Tillitt, D., Tysklind, M., Younes, M., Waern, F., Zacharewski, T., 1998. Toxic equivalency factors (TEFs) for PCBs, PCDDs, PCDFs for humans and wildlife. Environ. Health Perspect. 106 (12), 775-792.

Van den Berg, M., Birnbaum, L.S., Denison, M., De Vito, M., Farland, W., Feeley, M., Fiedler, H., Hakansson, H., Hanberg, A., Haws, L., Rose, M., Safe, S., Schrenk, D., Tohyama, C., Tritscher, A., Tuomisto, J., Tysklind, M., Walker, N., Peterson, R.E., 2006. The 2005 world health organization reevaluation of human and mammalian toxic equivalency factors for dioxins and dioxin-like compounds. Toxicolo. Sci. 93 (2), 223-241.

Van Straalen, N.M., Hoffmann, A.A., 2000. Review of experimental evidence for physiological costs of tolerance to toxicants. In: Kammenga, J.E., Laskowski, R. (Eds.), Demography of Ecotoxicology. John Wiley and Sons, New York, pp. 147161.

Van Veld, P., Westbrook, D., 1995. Evidence for depression of cytochrome P4501A in a population of chemically resistant mummichog (Fundulus heteroclitus). Environ. Sci. 3 (4), 221-234.

Weaver, G., 1984. PCB contamination in and around New Bedford. Mass. Environ. Sci. Technol. 18 (1), 22A-27A.

Wirgin, I., Roy, N.K., Loftus, M., Chambers, R.C., Franks, D.G., Hahn, M.E., 2011. Mechanistic basis of resistance to PCBs in Atlantic Tomcod from the Hudson River. Science 331, 1322-1325. 